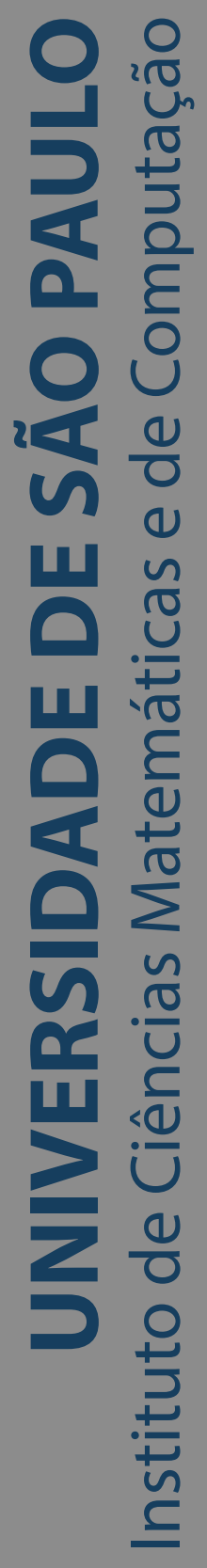

\title{
Geometria e GPS
}

\section{Hugo Cesar Faggian}

Dissertação de Mestrado do Programa de Mestrado Profissional em Matemática em Rede Nacional (PROFMAT) 

SERVIÇO DE PÓS-GRADUAÇÃO DO ICMC-USP

Data de Depósito:

Assinatura:

\section{Hugo Cesar Faggian}

\section{Geometria e GPS}

Dissertação apresentada ao Instituto de Ciências Matemáticas e de Computação - ICMC-USP, como parte dos requisitos para obtenção do título de Mestre em Ciências - Mestrado Profissional em Matemática em Rede Nacional. VERSÃO REVISADA Área de Concentração: Mestrado Profissional em Matemática em Rede Nacional

Orientador: Prof. Dr. Miguel Vinícius Santini Frasson 
Ficha catalográfica elaborada pela Biblioteca Prof. Achille Bassi e Seção Técnica de Informática, ICMC/USP, com os dados inseridos pelo(a) autor(a)

Faggian, Hugo Cesar

F154g Geometria e GPS / Hugo Cesar Faggian; orientador Miguel Vinícius Santini Frasson. -- São Carlos, 2019. $57 \mathrm{p}$.

Dissertação (Mestrado - Programa de Pós-Graduação em Mestrado Profissional em Matemática em Rede Nacional) -- Instituto de Ciências Matemáticas e de Computação, Universidade de São Paulo, 2019.

1. GPS. 2. Geometria. 3. Localização. 4. Circunferência. 5. Hipérbole. I. Frasson, Miguel Vinícius Santini, orient. II. Título.

Bibliotecários responsáveis pela estrutura de catalogação da publicação de acordo com a AACR2: Gláucia Maria Saia Cristianini - CRB - 8/4938

Juliana de Souza Moraes - CRB - 8/6176 


\section{Hugo Cesar Faggian}

\section{Geometry and GPS}

Master dissertation submitted to the Institute of Mathematics and Computer Sciences - ICMC-USP, in partial fulfillment of the requirements for the degree of Mathematics Professional Master's Program. FINAL VERSION

Concentration Area: Professional Master Degree Program in Mathematics in National Network

Advisor: Prof. Dr. Miguel Vinícius Santini Frasson 



\section{RESUMO}

FAGGIAN, H. C. Geometria e GPS. 2019. 57 p. Dissertação (Mestrado em Ciências - Mestrado Profissional em Matemática em Rede Nacional) - Instituto de Ciências Matemáticas e de Computação, Universidade de São Paulo, São Carlos - SP, 2019.

Este trabalho tem por objetivo mostrar a relação que existe entre a geometria, estudada no ensino básico, com o sistema de posicionamento global GPS, procurando trazer aos alunos uma visão diferenciada da matéria, de forma desafiadora e motivadora. $\mathrm{O}$ funcionamento do sistema GPS é baseado em princípios geométricos e físicos simples. São apresentadas atividades em sala de aula, mas restritas a duas dimensões, para aplicarmos desenho geométrico no papel e simplificar os cálculos para os alunos, já que não é necessário o acesso a grandes tecnologias.

Palavras-chave: Geometria, GPS, localização, circunferência, hipérbole. 



\section{ABSTRACT}

FAGGIAN, H. C. Geometry and GPS. 2019. 57 p. Dissertação (Mestrado em Ciências Mestrado Profissional em Matemática em Rede Nacional) - Instituto de Ciências Matemáticas e de Computação, Universidade de São Paulo, São Carlos - SP, 2019.

This work aims to show the relationship between geometry, studied in basic education, with the global positioning system GPS, aiming to bring students a differentiated view of the subject in a challenging and motivating way. The operation of the GPS system is based on simple geometric and physic principles. Classroom activities are presented, but restricted to two dimensions, in order to apply geometric draw and simplify computations for students, since no fancy technologies are needed.

Keywords: Geometry, GPS, localization, circumference, hyperbole. 



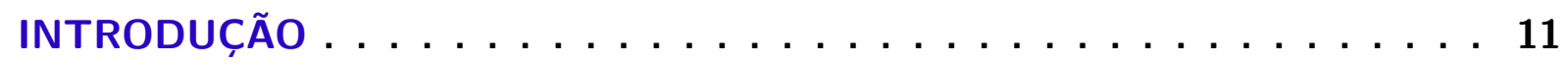

$1 \quad$ O SISTEMA GPS $\ldots \ldots \ldots \ldots \ldots \ldots \ldots \ldots$

$1.1 \quad$ Um pouco da história do GPS $\ldots \ldots \ldots \ldots \ldots$

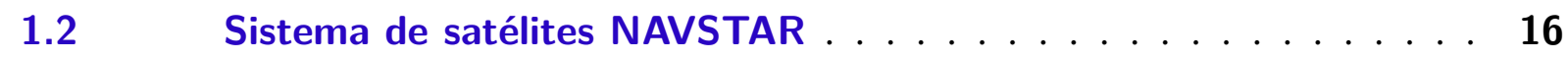

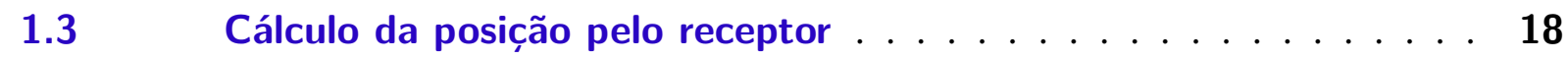

1.3.1 Cálculo algébrico da solução do problema em duas dimensões . . . 18

1.3.2 Resolução geométrica da posição em duas dimensões . . . . . . . 20

1.3.2.1 Traçando hipérboles com régua e barbante . . . . . . . . . . . . . 21

1.3.2.2 Traçando hipérboles no Geogebra . . . . . . . . . . . . . . . . . 22

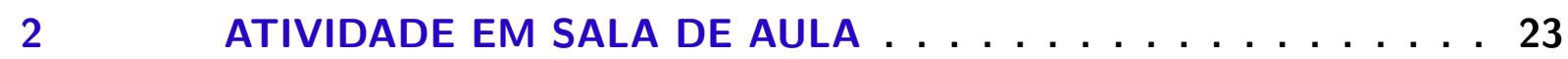

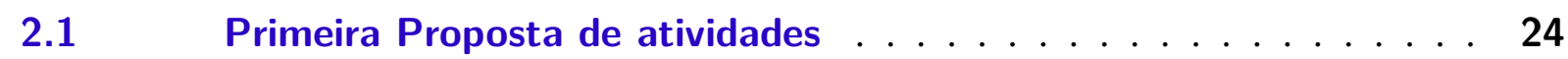

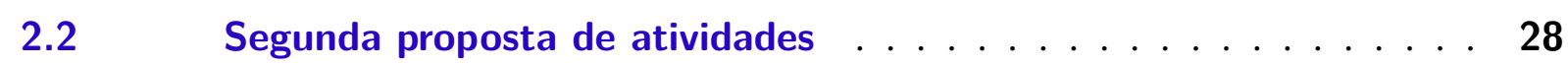

2.2.1 Roteiro para os alunos . . . . . . . . . . . . . . 29

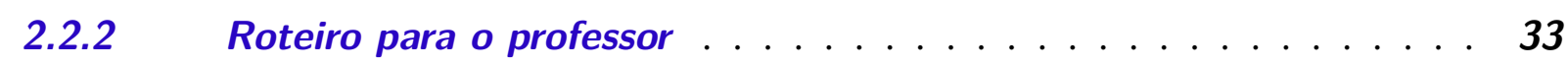

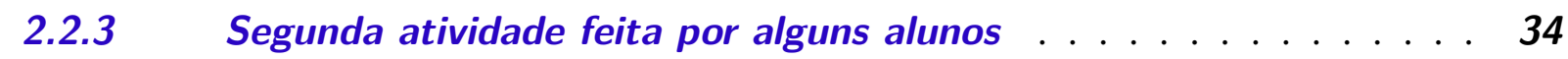

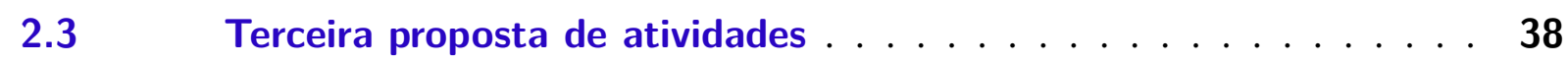

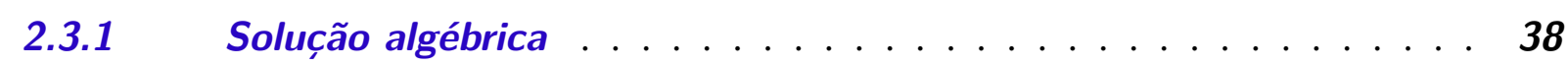

2.3.2 Solução geométrica . . . . . . . . . . . . . . . 39

2.3.3 Elaboração da atividade . . . . . . . . . . . . . . 40

2.3.4 Mais um exercício . . . . . . . . . . . . . . . . 40

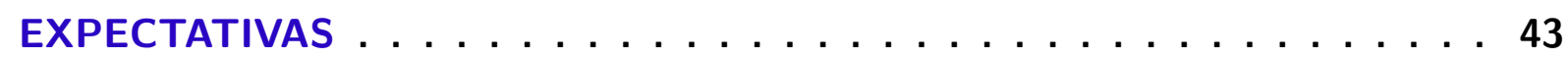

A MATERIAIS UTILIZADOS NAS ATIVIDADES DESENVOLVIDAS EM SALA DE AULA $\ldots \ldots \ldots \ldots \ldots \ldots$

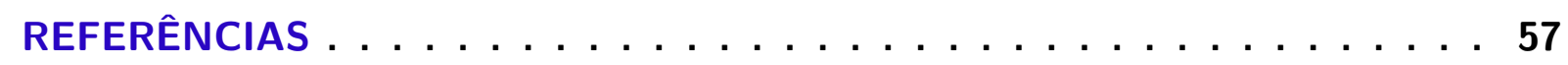



INTRODUÇÃO

O GPS é uma atraente aplicação da matemática, tendo sido abordado tanto em materiais didáticos (ALVES, 2005; ROUSSEAU; SAINT-AUBIN, 2015) quanto obras acadêmicas (SEGANTINE, 2005). O tema da dissertação busca despertar a curiosidade dos alunos e aproximar o estudo da matemática com a realidade, dando maior significação aos assuntos teóricos propostos. A aplicabilidade em sala de aula também foi levada em conta, já que não exige grandes recursos tecnológicos e pode ser adaptada aos diversos Ciclos da Educação Básica. As atividades foram preparadas focando trabalhar conceitos e habilidades abordadas pelo Currículo Paulista (FINI, 2012) e pela Base Nacional Comum Curricular (BNCC) (BRASIL, 2018) auxiliando professor e aluno no processo ensino-aprendizagem.

\section{Habilidades de Geometria na BNCC}

Quanto a atividade, os alunos foram bem receptivos quando mostrei para eles o desenvolvimento da atividade e expliquei que seria diferenciada, e também contemplaria habilidades que eles deveriam atingir ou já ter atingido em anos anteriores. As Habilidades da BNCC (Base Nacional Comum Curricular) (BRASIL, 2018), que são pauta de discussões desde a Constituição de 1988, que previa em seu Art. 210. Serão fixados conteúdos mínimos para o ensino fundamental, de maneira a assegurar formação básica comum e respeito aos valores culturais e artísticos, nacionais e regionais. e depois com a promulgação da Lei de Diretrizes e Bases da Educação Nacional (LDBEN), Lei 9.394, de 20 de dezembro de 1996, que em seu Artigo 26, regulamenta uma base nacional comum para a Educação Básica. Depois disso ainda foram muitas etapas até que em dezembro de 2017 é instituída a Base e as orientações para sua implementação. Até então segui o Currículo do Estado de São Paulo, que já tinha se adiantado e é bem semelhante na abordagem das habilidades.

As Habilidades principais da BNCC que podem ser trabalhadas são:

- (EF07MA22) Construir circunferências, utilizando compasso, reconhecê-las como lugar geométrico e utilizá-las para fazer composições artísticas e resolver problemas que envolvam objetos equidistantes.

- (EF08MA15) Construir, utilizando instrumentos de desenho ou softwares de geometria dinâmica, mediatriz, bissetriz, ângulos de $90^{\circ}, 60^{\circ}, 45^{\circ}$ e $30^{\circ}$ e polígonos regulares. 
- (EF09MA10) Demonstrar relações simples entre os ângulos formados por retas paralelas cortadas por uma transversal.

- (EF09MA12) Reconhecer as condições necessárias e suficientes para que dois triângulos sejam semelhantes.

- (EF09MA15) Descrever, por escrito e por meio de um fluxograma, um algoritmo para a construção de um polígono regular cuja medida do lado é conhecida, utilizando régua e compasso, como também softwares.

- (EF09MA16) Determinar o ponto médio de um segmento de reta e a distância entre dois pontos quaisquer, dadas as coordenadas desses pontos no plano cartesiano, sem o uso de fórmulas, e utilizar esse conhecimento para calcular, por exemplo, medidas de perímetros e áreas de figuras planas construídas no plano.

- (EM13MAT201) Propor ou participar de ações adequadas às demandas da região, preferencialmente para sua comunidade, envolvendo medições e cálculos de perímetro, de área, de volume, de capacidade ou de massa.

- (EM13MAT315) Investigar e registrar, por meio de um fluxograma, quando possível, um algoritmo que resolve um problema.

- (EM13MAT301) Resolver e elaborar problemas do cotidiano, da Matemática e de outras áreas do conhecimento, que envolvem equações lineares simultâneas (SISTEMAS), usando técnicas algébricas e gráficas, com ou sem apoio de tecnologias digitais.

Há também Habilidades que são observadas no Currículo Paulista

- $1^{\circ}$ ANO ENSINO MÉDIO - $4^{\circ}$ Bimestre

Saber inscrever e circunscrever polígonos regulares em circunferências dadas

- $3^{\circ}$ ANO ENSINO MÉDIO - $1^{\circ}$ Bimestre

Saber usar de modo sistemático sistemas de coordenadas cartesianas para representar pontos, figuras, relações, equações

Saber resolver problemas práticos associados a equações e inequações lineares

Saber identificar as equações da circunferência e das cônicas na forma reduzida e conhecer as propriedades características das cônicas

\section{Sobre o autor e onde esse trabalho foi aplicado}

Professor da rede estadual desde 2013, comecei como professor auxiliar de matemática, acompanhando as aulas da professora titular, quando ainda estava cursando o último ano de 
Licenciatura em Ciências Exatas na USP - São Carlos, curso interunidades, gerenciado pelo IFSC - Instituto de Física de São Carlos e como escolhi habilitação em Matemática, fiz os últimos períodos no ICMC - Instituto de Ciências Matemáticas e de Computação. Ingressei como professor titular de matemática na rede estadual paulista, através de concurso público no em 2014, na Escola Estadual prof. Arlindo Bittencourt, na cidade de São Carlos-SP, bairro Vila Monteiro, recebe alunos de Ensino Fundamental 2 e de Ensino Médio, nos períodos matutino e vespertino. Escola de tradição na cidade, recebe alunos de todos os bairros, mas principalmente dos arredores, constituído pela Vila Isabel e do C.D.H.U., bairros de moradia de famílias humildes, infelizmente com casos de drogadição e alguns casos de tráfico.

Os índices da escola de acordo com o IDESP (Índide de Desenvolvimento da Educação do estado de São Paulo), que é o índice pelo qual as escolas podem referenciar seu ensino de acordo com a respectiva Diretoria Regional que está vinculada e também todo o Estado, 3,08 e 2,82, respectivamente no Ensino Fundamental ( $\left.9^{\circ} \mathrm{ANO}\right)$ e Ensino Médio ( $3^{\circ} \mathrm{ANO}$ ), que em comparação com a Diretoria de São Carlos, 3,71 e 2,75, e o todo o Estado 3,38 e 2,51, respeitadas as respectividades, encontramos um índice baixo, porém o Ensino Médio supera o IDESP Estadual, coisa que não acontece no Fundamental. 



\section{O SISTEMA GPS}

\subsection{Um pouco da história do GPS}

O homem sempre buscou uma maneira de se localizar na superfície do planeta, fosse por pontos fixos, como montanhas, cordilheiras, riachos, fosse por meio das estrelas, mapas, bússolas e astrolábios... Essa tecnologia foi se desenvolvendo à medida em que foram necessárias viagens para ampliar o domínio de terras e busca por "novas pastagens", com animais para caça, acesso facilitado à água e terras férteis para plantações. Conforme a história foi se desenvolvendo, quem sabia qual caminho seguir, por saber se localizar, tinha vantagens em guerras, disputas de terra e por esse motivo o investimento em maneiras novas de localização em nossa superfície sempre teve alta prioridade por parte dos governantes, principalmente de países que estão constantemente em guerra, vigiando seus adversários e consequentemente sendo vigiados.

Nos dias atuais, um dos sistemas mais populares é o GPS (Global Positioning System Sistema de Posicionamento Global), talvez por ser o primeiro a garantir uma precisão significativa para uso civil, estando à mão de qualquer pessoa com um celular moderno. Esse sistema foi criado pelo governo dos Estados Unidos, através do Departamento de Defesa (DoD - sigla em inglês) na década de 1970, que lançou seus satélites nos anos seguintes, o primeiro em 1978. Mas a constelação de satélites, conhecida como NAVSTAR, só esteve em pleno funcionamento em 1993, à época com 24 satélites em funcionamento pleno. O sistema foi aberto para uso civil logo após, porém havia encriptação do sinal de alta precisão, de uso restrito militar, e acréscimo de ruído no sinal aberto, para que ocorresse um erro proposital de aproximadamente cem metros no posicionamento do receptor. Em 2000 esse acréscimo de ruído foi removido por ordem do então presidente norte americano, Bill Clinton ${ }^{1}$.

Hoje, um aparelho receptor de sinal GPS comum tem uma precisão média de quatro metros, o acesso foi popularizado pela presença da tecnologia nos smartphones em aplicativos

$1 \quad<$ https://www.gps.gov/systems/gps/performance/accuracy/> 
à mão como o Google Maps ou o Apple Maps e grande parte dos alunos tem contato com o sistema, fazendo o estudo do GPS um tema motivador e interessante para explorar o estudo de circunferências a partir do final do Ensino Fundamental ou até cônicas no ano final do Ensino Médio regular. De modo simplificado podemos explicar como é seu funcionamento e como os satélites trabalham e fazem com que em instantes possamos calcular nossa localização com bastante precisão, possibilitando outras aplicações como cálculo de trajetos no trânsito. Há celulares hoje que prometem uma precisão de $30 \mathrm{~cm}^{2}$, mas para isso usam dois tipos de sistemas de posicionamento, como o próprio GPS, americano, e o Glonass, russo, fazendo com que possamos localizar e/ou marcar algo como a tampa de um bueiro em um mapa, ou mesmo uma tubulação subterrânea, sem o incômodo de marcarmos a superfície com algo físico, e outras inúmeras aplicações e vantagens que podem ser desenvolvidas conforme a nossa necessidade.

\subsection{Sistema de satélites NAVSTAR}

O sistema GPS funciona hoje com uma constelação de 32 satélites NAVSTAR, sendo 24 operacionais e o restante reservas, prontos para entrar em ação caso ocorra falha nos satélites ativos, que orbitam a Terra com um ciclo aproximado de duas voltas por dia, de forma que, em qualquer ponto da superfície terrestre, ao menos quatro satélites estejam visíveis e nunca estejam coplanares, condições essenciais para que a posição possa ser determinada de maneira única ((ALVES, 2005) mostra este teorema). Os satélites são monitorados por bases fixas na superfície e comunicam-se entre si verificando constantemente sua trajetória e posição com a máxima precisão, efetuando ajustes nas informações caso necessário. Cada satélite está equipado com um relógio atômico de alta precisão, do qual daremos mais detalhes adiante. Os satélites emitem simultaneamente um sinal eletrônico de GPS que caminha à velocidade da luz, em que está codificada a assinatura do satélite, sua posição e o horário de emissão. A Figura 1 ilustra os seis planos orbitais onde orbitam os satélites NAVSTAR.

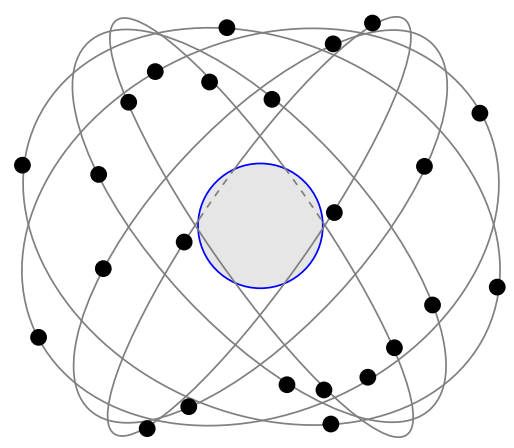

Figura 1 - Os seis planos orbitais dos satélites NAVSTAR ${ }^{3}$.

2 <https://www.tecmundo.com.br/produto/122404-novo-sistema-gps-smartphones-ter-precisao-30-cm. htm>

3 Créditos da Imagem: (ROUSSEAU; SAINT-AUBIN, 2015, p. 3) 
Um receptor no solo grava constantemente os sinais que chegam. Tal receptor, barato comparando-se com os relógios atômicos instalados nos satélites, não está provido de relógio sincronizado como os relógios dos satélites, portanto ao receber uma mensagem do satélite, não tem como saber por quanto tempo esse sinal viajou até captá-lo, mas ao observar o espectro de sinais que recebe, pode saber pelos horários codificados nas mensagens, os tempos relativos $\Delta t_{i}=t_{i}-t_{1}$, onde $t_{1}$ é o horário em que captou o sinal de satélite NAVSTAR - consequentemente o mais próximo, à distância $d_{1}$ do receptor — com a máxima precisão que seu relógio permitir. Esses tempos relativos $\Delta t_{i}$ são transformados em distâncias relativas $\Delta d_{i}$ através da relação

$$
c=\frac{\Delta d_{i}}{\Delta t_{i}}
$$

na qual $c$ é a velocidade da luz, estimada em $299.792 .458 \mathrm{~m} / \mathrm{s} \approx 3 \times 10^{8} \mathrm{~m} / \mathrm{s}$. Então, conhecendo algumas distâncias relativas $\Delta d_{i}=d_{i}-d_{1}$ e a posição $S_{i}$ dos satélites, pelo processo conhecido como trilateração, pode-se calcular coordenadas de um ponto na Terra. Veja a Figura 2.

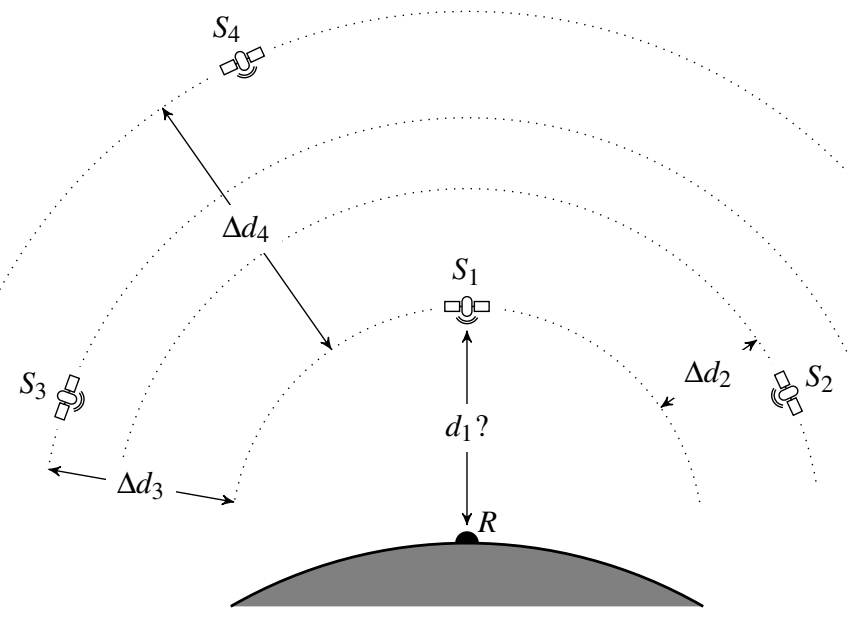

Figura 2 - Exemplo com quatro satélites visíveis: apenas observando os sinais que chegam, o receptor $R$ não tem como calcular $d_{1}$, mas consegue calcular $\Delta d_{2}, \Delta d_{3}$ e $\Delta d_{4}$.

O cálculo preciso das distâncias só é possível porque os satélites são equipados com relógios atômicos, que estão sincronizados. Estima-se que um relógio atômico tenha o erro de um segundo em trezentos mil anos, e como são constantemente atualizados, podemos dizer que esse erro é desprezível. Deve-se levar em conta que os satélites estão em uma órbita de $\approx 20.200 \mathrm{~km}$ da superfície a uma velocidade de $\approx 14000 \mathrm{~km} / \mathrm{h}$ e, segundo Einstein, o espaço e a gravidade distorcem o tempo, ou seja, o tempo passa mais rápido em órbita que na superfície, por isso é imprescindível que os relógios sejam sincronizados constantemente, uma vez que, como o sinal é extremamente rápido, um erro de um microssegundo $\left(10^{-6} \mathrm{~s}\right)$ acarreta uma perda de precisão de $c \times 10^{-6}=300 \mathrm{~m}$, um erro grande demais que deixaria o sistema sem serventia.

Nas práticas em sala de aula para a abordagem do assunto com os alunos trataremos como se os satélites utilizassem circunferências para cálculos de localização, pois são mais próximas 
da realidade e podem ser facilmente contextualizadas, demonstradas, desenhadas, equacionadas e trabalhadas. O trabalho do professor seria praticamente inviabilizado caso colocássemos apenas exemplos contendo hipérboles.

\subsection{Cálculo da posição pelo receptor}

A fim de facilitar a compreensão por parte dos alunos, simplificando a explicação e demonstração, o estudo que faremos será desenvolvido em duas dimensões, e o raciocínio estende-se naturalmente para três dimensões.

Faremos a seguir, na Seção 1.3.1, uma resolução algébrica para o problema de encontrar a posição do receptor. Os passos que foram executados para um caso concreto estão ilustrados na Seção 2.3.1, p. 38.Mais adiante, na Seção 1.3.2, uma versão puramente geométrica da solução será discutida.

\subsubsection{Cálculo algébrico da solução do problema em duas dimensões}

Vimos que o problema consiste em encontrar as coordenadas de $P=(x, y)$, dadas as localizações dos pontos de referência $S_{1}, S_{2}$ e $S_{3}$ e as distâncias relativas $\Delta d_{2}$ e $\Delta d_{3}$. Sendo as distâncias $d_{1}, d_{2}$ e $d_{3}$ incógnitas, devemos resolver o seguinte sistema de equações quadráticas, onde cada linha é uma equação de circunferência com centro nos pontos $S_{i}$ :

$$
\left\{\begin{array}{l}
P S_{1}=d_{1} \\
P S_{2}=d_{2}=d_{1}+\Delta d_{2} \\
P S_{3}=d_{3}=d_{1}+\Delta d_{3}
\end{array}\right.
$$

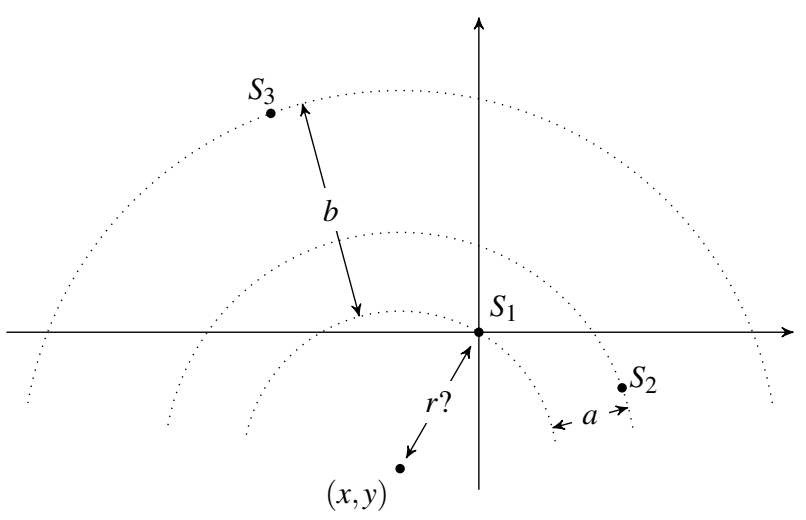

Figura 3 - Ilustração das incógnitas para a resolução algébrica do GPS.

Utilizando geometria analítica, se necessário fazendo uma translação no sistema de coordenadas de forma que $S_{1}$ seja a origem, isto é, $S_{1}=0$, e também eliminando símbolos fazendo $r=d_{1}$ (incógnita), $a=\Delta d_{2}, b=\Delta d_{3}, S_{2}=\left(x_{a}, y_{a}\right)$ e $S_{3}=\left(x_{b}, y_{b}\right)$, como na figura 3 , 
(1.1) torna-se o sistema de equações

$$
\begin{gathered}
x^{2}+y^{2}=r^{2} \\
\left(x-x_{a}\right)^{2}+\left(y-y_{a}\right)^{2}=(r+a)^{2} \\
\left(x-x_{b}\right)^{2}+\left(y-y_{b}\right)^{2}=(r+b)^{2}
\end{gathered}
$$

que, desenvolvendo, torna-se

$$
\begin{gathered}
x^{2}+y^{2}=r^{2} \\
x^{2}-2 x x_{a}+x_{a}^{2}+y^{2}-2 y y_{a}+y_{a}^{2}=r^{2}+2 r a+a^{2} \\
x^{2}-2 x x_{b}+x_{b}^{2}+y^{2}-2 y y_{b}+y_{b}^{2}=r^{2}+2 r b+b^{2}
\end{gathered}
$$

Subtraindo a primeira equação das outras, obtemos o sistema linear

$$
\left\{\begin{array}{l}
-2 x x_{a}-2 y y_{a}=2 r a+a^{2}-x_{a}^{2}-y_{a}^{2} \\
-2 x x_{b}-2 y y_{b}=2 r b+b^{2}-x_{b}^{2}-y_{b}^{2}
\end{array}\right.
$$

que pode ser reescrito na forma matricial como

$$
A z=k+r d
$$

onde

$$
A=\left(\begin{array}{ll}
x_{a} & y_{a} \\
x_{b} & y_{b}
\end{array}\right), \quad z=\left(\begin{array}{l}
x \\
y
\end{array}\right), \quad k=\frac{1}{2}\left(\begin{array}{c}
x_{a}^{2}+y_{a}^{2}-a^{2} \\
x_{b}^{2}+y_{b}^{2}-b^{2}
\end{array}\right), \quad d=-\left(\begin{array}{l}
a \\
b
\end{array}\right)
$$

Aqui fica claro que, como os pontos $S_{1}, S_{2}$ e $S_{3}$ são não colineares, os vetores $\overrightarrow{S_{1} S_{2}}$ e $\overrightarrow{S_{1} S_{3}}$ são linearmente independentes, e portanto $\operatorname{det} A \neq 0$, de forma que o sistema é possível e determinado.

Aqui, como todos os dados são algébricos, recorreremos a equações matriciais para expressar as soluções.

Fazendo

$$
\left(\begin{array}{l}
u \\
v
\end{array}\right)=A^{-1} k, \quad\left(\begin{array}{l}
s \\
t
\end{array}\right)=A^{-1} d
$$

obtemos

$$
\begin{aligned}
& x=u+r s \\
& y=v+r t
\end{aligned}
$$

Substituindo (1.5) em (1.2), expandindo e agrupando os coeficientes das potências de $r$, obtemos a equação do $2^{\circ}$ grau em $r$

$$
\left(s^{2}+t^{2}-1\right) r^{2}+2(s u+t v) r+\left(u^{2}+v^{2}\right)=0 .
$$

Como o problema parte de uma solução (a posição do receptor é sempre a solução!), a equação quadrática (1.6) tem uma ou possivelmente duas soluções. Encontradas as soluções $r$, 
através da fórmula de Bháskara, expressão que não colocaremos aqui, substituímos seus valores em (1.5), obtendo assim as soluções.

Nota: Quando houver duas soluções, uma delas deve ser descartada com base em regiões onde soluções são admissíveis ou inadmissíveis. No caso do GPS, quando há duplicidade, a própria disposição dos satélites foi pensada de forma que, em caso de duplicidade, uma das soluções absurdamente absurdamente longe da Terra, e portanto a solução admissível é sempre única.

\subsubsection{Resolução geométrica da posição em duas dimensões}

A Geometria é um dos ramos mais ricos da matemática, e percebemos que seu estudo e valorização tem diminuído paulatinamente ao longo dos anos no Brasil (PEREIRA, 2001). Veremos como é mais simples a solução geométrica do problema do que a solução algébrica. Essa forma solução pode estimular o interesse dos alunos pelas cônicas.

Especialmente após a $1^{\text {a }}$ Guerra Mundial, haviam outros sistemas de navegação baseados em hipérboles, como o LORAN (sigla para LOng RAge Navigation), desativados poco a pouco a partir da década de 1980. Uma explanação desses sistemas pode ser encontrado em (SEGANTINE, 2005) e na videoaula (LINARES, 2016).

Vimos que as equações da localização do receptor num plano podem ser escritas como

$$
\left\{\begin{array}{l}
P S_{1}=d_{1} \\
P S_{2}=d_{1}+\Delta d_{2} \\
P S_{3}=d_{1}+\Delta d_{3}
\end{array}\right.
$$

onde $P S_{i}$ é a distância do ponto $P$ ao ponto de referência $S_{i}$, sendo $P$ e $d_{1}$ as incógnitas do problema.

Subtraindo a primeira equação das demais, obtemos o sistema

$$
\left\{\begin{array}{l}
P S_{2}-P S_{1}=\Delta d_{2} \\
P S_{3}-P S_{1}=\Delta d_{3}
\end{array}\right.
$$

Ora, a hipérbole de focos $F_{1}$ e $F_{2}$ é definida como o lugar geométrico dos pontos $P$ cuja diferença das distâncias aos focos é constante. Segue que os pontos $P$ que satisfazem a equação

$$
P F_{2}-P F_{1}=d
$$

é precisamente o ramo da referida hipérbole mais próximo do foco $F_{1}$. Veja a Figura 4 .

Assim, o sistema (1.7) pode ser interpretado pela interseção dos ramos das hipérboles $\alpha: P S_{2}-P S_{1}=\Delta d_{2}$ e $\beta: P S_{3}-P S_{1}=\Delta d_{3}$ que estão mais próximos do foco comum $S_{1}$. Veja a Figura 5

Note que esse ponto de vista geométrico ilustra bem a possibilidade de que haja duas soluções possíveis, pois dois ramos de hipérbole podem intersectar-se em dois pontos. 


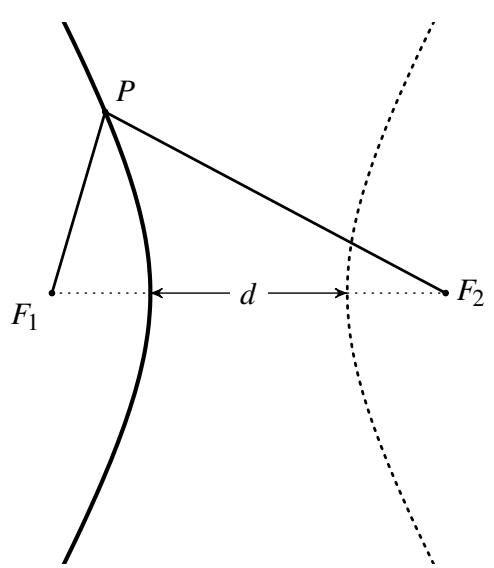

Figura 4 - O ramo de hipérbole mais próximo de $F_{1}$ é o lugar geométrico dos pontos $P$ que satisfazem a equações do tipo $P F_{2}-P F_{1}=d$.

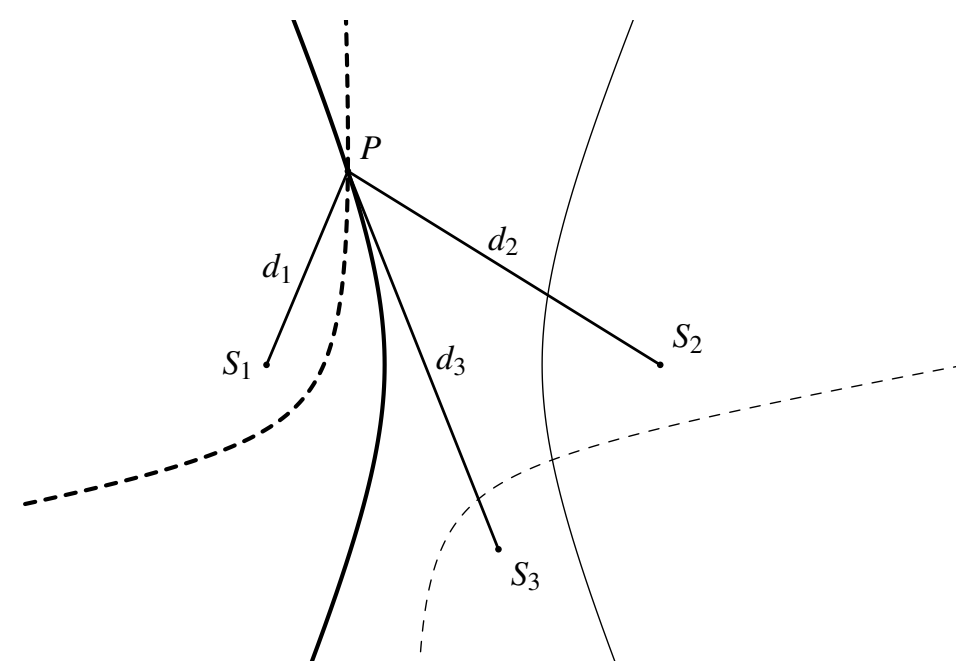

Figura 5 - Solução geométrica do sistema $\left\{P S_{2}-P S_{1}=\Delta d_{2}, P S_{3}-P S_{1}=\Delta d_{3}\right\}$ onde $\Delta d_{2}$ e $\Delta d_{2}$ são conhecidos. A hipérbole com focos $S_{1}$ e $S_{2}$ está desenhada em traço contínuo, e a com focos $S_{1}$ e $S_{3}$ está desenhada tracejada. Os ramos próximos de $S_{1}$ estão destacados, e a solução $P$ está em sua interseção.

\subsubsection{Traçando hipérboles com régua e barbante}

A grande dificuldade é traçar as hipérboles na lousa ou no caderno. Há um truque para desenhar a hipérbole usando uma régua e um barbante (de comprimento menor que a régua): uma extremidade da régua é fixada num foco, uma extremidade do barbante é fixada no outro foco e as extremidades livres da régua e do barbante são unidas. Então com o lápis deslizando na régua e mantendo o barbante esticado, traça-se uma figura que é um ramo de hipérbole. Veja a Figura 6. O truque funciona pois, quando movemos o lápis (cuja ponta está em $P$ ) na direção do foco $F_{1}$ como na figura, tanto o comprimento $P F_{1}$ quanto o barbante $P F_{2}$ diminuem a mesma quantidade, mantendo constante a diferença $P F_{1}-P F_{2}$, portanto o traçado é de um trecho de ramo de hipérbole. Para uma explicação em vídeo, veja (ATRACTOR, 2014). 


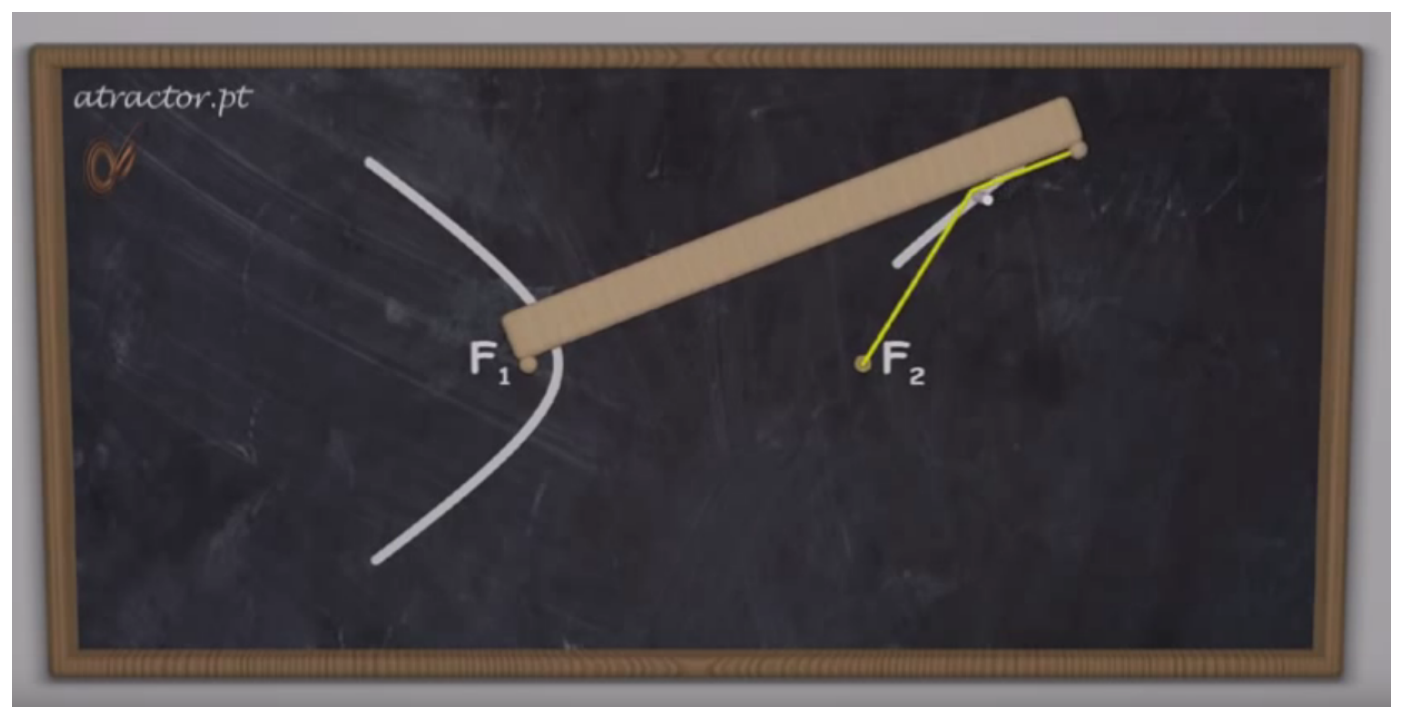

Figura 6 - Traçado da hipérbole com régua e barbante ${ }^{4}$.

\subsubsection{Traçando hipérboles no Geogebra}

O software de geometria dinâmica Geogebra pode ser uma valiosa ferramenta de geometria, principalmente quando certas construções de traçados não estão disponíveis pelos instrumentos clássicos, a régua e o compasso.

O Geogebra permite a entrada de hipérboles através do comando

Hipérbole( Foco, Foco, Comprimento do semieixo )

Assim, para traçar a hipérbole $P B-P A=d$, definimos os pontos $A$ e $B$, e o número $d$ se quisermos, então podemos escrever

Hipérbole( $\mathrm{A}, \mathrm{B}, \mathrm{d} / 2$ )

com o inconveniente (no nosso caso) de que os dois ramos da hipérbole serão traçados. Nossa aplicação aproveita apenas aquele ramo mais próximo do foco $A$.

Para ilustrar esses passos num caso concreto, um roteiro passo a passo de resolução em Geogebra encontra-se na Seção 2.3.2, p. 39.

$\overline{4}$ Créditos da imagem: portal Atractor.pt, https://youtu.be/ETV_bWAPOqU. 


\section{ATIVIDADE EM SALA DE AULA}

As atividades a seguir são propostas para os professores aplicarem em sala, tanto em grupos quanto individualmente. Todas contemplam o Currículo do Estado de São Paulo, e o docente pode adaptar de acordo com sua realidade. O material principal a ser utilizado é o compasso, e o professor necessitará imprimir algum material.

Com exceção da terceira, as atividades propostas neste capítulo foram aplicadas em salas de aula do ensino médio da Escola Estadual Prof. Arlindo Bittencourt e da Escola Estadual Prof. Gabriel Félix do Amaral, na cidade de São Carlos-SP, no ano de 2018.

Para tratarmos de maneira mais próxima da realidade do aluno, utilizamos apenas circunferências nas atividades, podendo utilizar esferas nas explicações. Para dar acesso ao tema, a atividade foi dividida em vários níveis de dificuldade, começando com a trilateração, que requer um contato básico com elementos de geometria e desenho geométrico, podendo ser aplicada já a partir do $9^{\circ}$ ano do ensino fundamental, tomando como base o Currículo do Estado de São Paulo (FINI, 2012).

Apenas a terceira atividade proposta é mais próxima da situação real do funcionamento do GPS, no entanto fornecendo já prontas as diferenças de distâncias da posição aos pontos de referência, deixando de lado o conceito físico de velocidade para o cálculo dessas distâncias em função da diferença do tempo de chegada dos sinais e sua velocidade. Um professor que planeja esse aprofundamento em classes avançadas pode ajustar o problema fornecendo os tempos de recepção do sinal aos alunos. Aqui, o aluno deve dominar tópicos como a equação da circunferência no plano, desenvolvimento de produtos notáveis e noções de resolução de sistemas lineares e resolução de equações do $2^{\circ}$ grau, tópicos abordados no $1^{\circ}$ bimestre do $3^{\circ}$ ano do Ensino Médio de acordo com o Currículo do Estado de São Paulo, podendo ser aplicado em turmas mais avançadas em que tais tópicos já tenham sido estudados.

Finalmente, propomos o mesmo problema, agora resolvido geometricamente usando o conceito de hipérboles, tópico visto por volta da metade do $3^{\circ}$ ano do Ensino Médio. Inclusive, 
esta atividade pode mostrar uma bela aplicação das hipérboles, motivando o interesse dos alunos pelo tema!

Lembramos que a Base Nacional Comum Curricular (BNCC) foi aprovada no ano de 2018, estando a base curricular do Estado de São Paulo já próximo à base nacional, logo as alterações serão minímas e essas atividades não perderão aplicabilidade com as alterações mínimas eventualmente efetuadas.

Conceitos e metodologias a serem aplicadas serão explicados em cada uma das atividades, assim como as experiências e considerações que o professor julga serem importantes ressaltar.

\subsection{Primeira Proposta de atividades}

Nesta primeira atividade, trabalhamos o conceito de trilateração. O aluno precisa dispor apenas de um compasso para bem trabalhá-la. É adequada para alunos a partir do $9^{\circ}$ ano do Ensino Fundamental. Estima-se que o professor deve utilizar ao menos quatro aulas para o desenvolvimento da atividade e mais duas para a avaliação.

Cada aluno recebeu uma folha de enunciado e dois mapas da região central da cidade de São Carlos, onde estão marcados 28 pontos de interesse na cidade e três pontos de referência, a saber a rotatória do Carrefour (Santa Felícia), o balão do bonde da Vila Nery e a igreja Santo Antônio (Vila Prado).

No primeiro exercício proposto, são dadas três distâncias de uma localização aos pontos de referência e os alunos deveriam descobrir o que está nessa localização. Cada folha de enunciado fornecia a localização de cinco dos pontos a serem encontrados. Para evitar que um aluno tivesse sua curiosidade estragada, as folhas de enunciado eram todas distintas, com uma seleção de cinco lugares dentre os 28 marcados.

O segundo exercício é a atividade inversa: o aluno escolhe uma localização e deve, com o compasso e a escala impressa, encontrar as distâncias aos pontos de referência e preencher a tabela das distâncias.

O mapa fornecido tinha uma escala impressa na mesma página, em centímetros abaixo e com a distância real acima. Essa escala impressa tem a vantagem de manter a proporção mediante uma ampliação ou redução no processo de fotocópia.

Nas figuras 7, 8 e 9, vemos a execução da atividade por parte de um aluno. A folha de resposta preenchida ao final da atividade encontra-se na Figura 7. 


\section{Atividade GPS: triangulação}

Tomando pontos de referência:

$$
\begin{aligned}
& \text { A - Rotatória do Carrefour (Santa Felícia) } \\
& \text { B - Balão do bonde da Vila Nery } \\
& \text { C - Igreja Santo Antônio (Vila Prado) }
\end{aligned}
$$

\begin{tabular}{|c|c|c|c|}
\hline Local & Até A (m) & Até B (m) & Até $\mathrm{C}(\mathrm{m})$ \\
\hline $1^{\circ}$ & 3400 & 1920 & 1450 catidial \\
\hline $2^{\circ}$ & 3500 & 2570 & 740 Eestacio Eernonarea \\
\hline $3^{\circ}$ & 1660 & 3060 & 3260 cantódnomo \\
\hline $4^{\circ}$ & 3330 & 2720 & 720 t'rupa- Umpo \\
\hline $5^{\circ}$ & 2120 & 2650 & 2230 开 \\
\hline
\end{tabular}

1) Você é capaz de dizer o que se encontra nos locais abaixo, dadas as distâncias aos pontos A, B e C?

2) Escolha alguns pontos do mapa e calcule as distâncias deles aos pontos de referência.

\begin{tabular}{clll}
\hline Local & Até $\mathrm{A}(\mathrm{m})$ & Até B $(\mathrm{m})$ & Até $\mathrm{C}(\mathrm{m})$ \\
\hline $1^{\circ}$ & 2120 & 2900 & 1950 \\
\hline $2^{\circ}$ & 3820 & 1040 & 2500 \\
\hline $3^{\circ}$ & 3000 & 1970 & 1880 \\
\hline $4^{\circ}$ & 2550 & 2250 & 2250 \\
\hline
\end{tabular}

\section{Locais assinalados no mapa}
1. Catedral de São Carlos
2. Prefeitura
3. Teatro municipal
4. Álvaro Guião
5. Colégio São Carlos
6. Mercado municipal
7. Senac
8. Universidade de São Paulo - USP
9. Estação Ferroviária
10. Senai
11. Poupa-Tempo
12. Shopping Iguatemi
13. São Carlos Club
14. Igreja N. Sra. Fátima e Livraria Querigma
15. Santa Casa
16. Campo do Rui
17. Forum
18. Balão do Bonde da Vila Nery
19. Igreja Santo Antônio (Vila Prado)
20. Rodoviária
21. Kartódromo
22. Shopping Passeio São Carlos
23. Hospital-Escola
24. Universidade Federal de São Carlos
25. Carrefour (Santa Felicia)
26. Sesi
27. Parque Ecológico
28. Cemitério N. Sra. do Carmo

Figura 7 - Página resposta às atividades. 
(1)

\section{SÃO CARLOS - Mapa da região central}
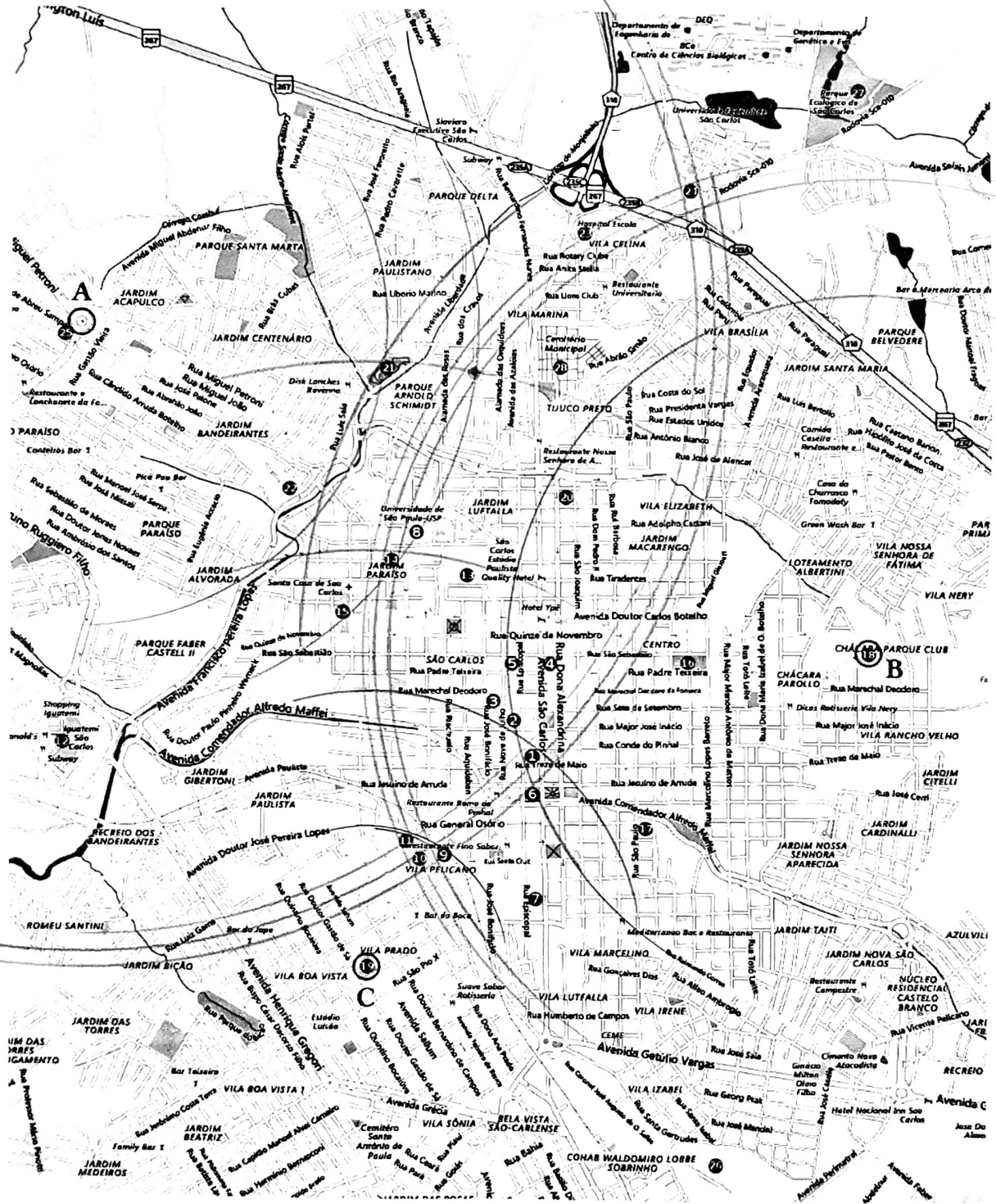

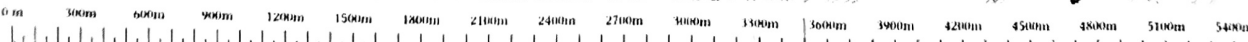
( का

$\begin{array}{llllllllllllllllll}0 & 1 & 2 & 3 & 4 & 5 & 6 & 7 & 8 & 9 & 10 & 11 & 12 & 13 & 14 & 15 & 16 & 17\end{array}$

Figura 8 - Mapa onde foi executada a atividade de trilateração. 
2

SÃO CARLOS - Mapa da região central

Escala: $1: 30.000 \quad(1 \mathrm{~cm}$ no mapa $=300 \mathrm{~m})$

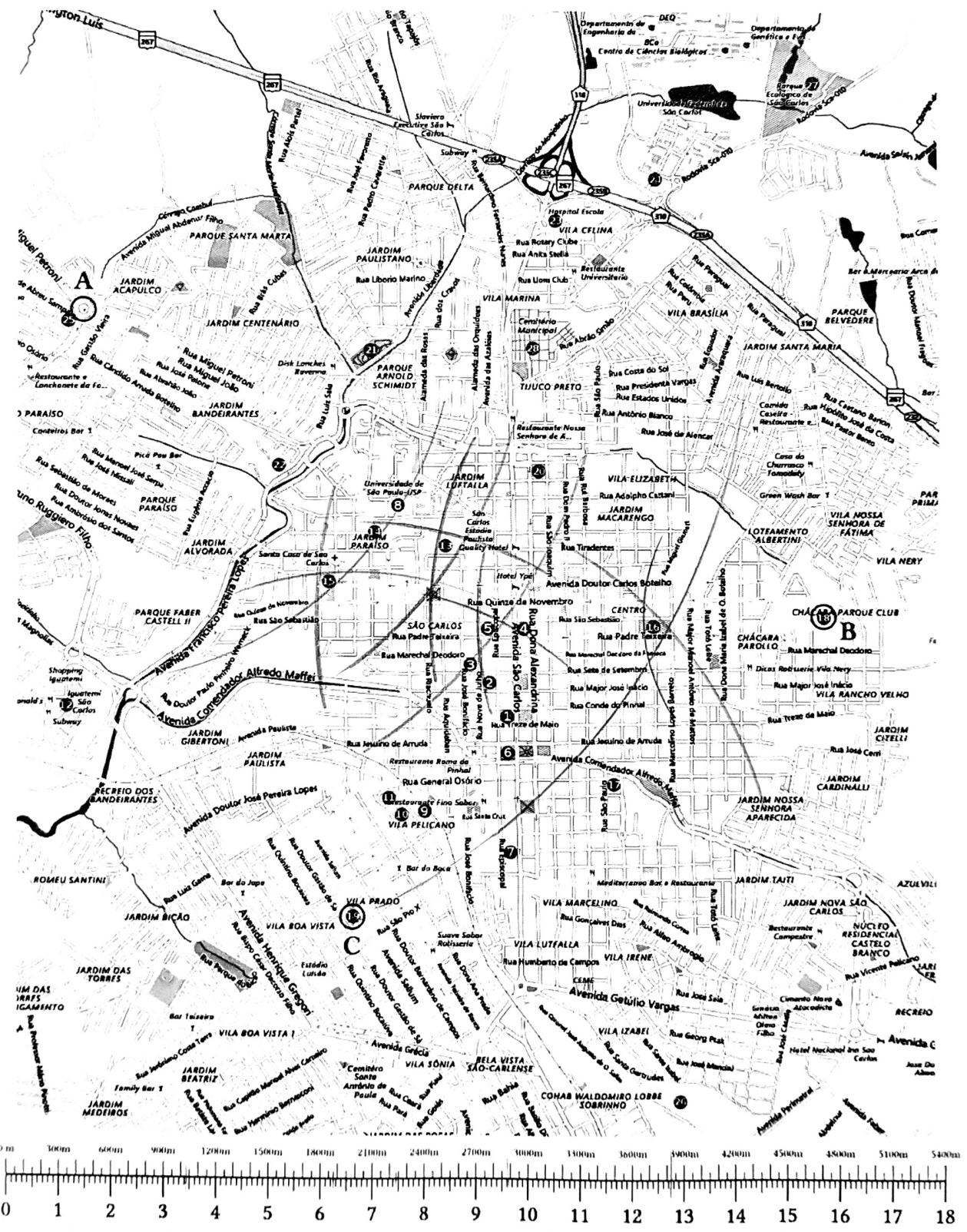

Figura 9 - Mapa onde foi executada a atividade de descobrir as distâncias aos pontos de referência. 


\subsection{Segunda proposta de atividades}

As recomendações são para aplicação no Ensino Médio e o nível de aprofundamento e cobrança dependerá do desenvolvimento, dos conhecimentos prévios dos alunos e o tempo disponibilizado para as aplicações. Caso o professor decida aplicar no Ensino Fundamental, é necessário que os alunos tenham noções de desenho geométrico, já que a atividade exige secção de segmentos em partes iguais.

A atividade tenta trazer o lúdico, com uma estória de detetive a ser desvendada, a fim de aguçar o interesse dos alunos. Foram trabalhados os conceitos de escala, através de distâncias entre "torres" marcadas no mapa.

O objetivo principal da atividade é mostrar para os alunos que mesmo sabendo as distâncias relativas a pontos fixos, não é tão simples localizar alguém pelo método de trilateração. Das informações prestadas através das torres no mapa e tabelas no roteiro, o aluno deve dividir e manipular os segmentos conhecidos para chegar às distâncias fornecidas pela empresa de telefonia móvel do investigado.

Apesar de não utilizarmos a trilateração diretamente nesta atividade, os alunos devem terminá-la entendendo como o sistema GPS funciona basicamente. Além do principal foco o professor aborda escalas e divisão de segmentos com régua e compasso.

Os pontos e distâncias que estão representados no mapa e na tabela foram pensados para gerar conflitos e discussões sobre o número "ideal" de pontos que devem servir de referência e posicionamento relativo desses pontos, por exemplo, se forem colineares, as informações, de três ou mais pontos, geram dúvidas quanto à localização do receptor. Os alunos devem ajudar na investigação e tirar suas próprias conclusões após representarem as distâncias no mapa. Para uma representação correta é necessário que tenham entrado em contato com secção de segmentos, em desenho geométrico, previsto para o oitavo ano de Ensino Fundamental, recomenda-se ao colega uma revisão de conceitos geométricos e suas construções pois pode ser que os alunos não se lembrem ou nem tenham tido contato com o conteúdo, como o Teorema de Tales e as devidas construções de retas paralelas - aqui o professor pode utilizar a técnica prática com uma régua e um esquadro - , oque pode levar algumas aulas a mais, mas é recompensador pois a atividade fluirá de maneira mais fácil e coerente em relação à visão dos alunos. Essa dificuldade a mais do problema se deve à preocupação sobre distorções que podem ocorrer durante a impressão dos mapas, e da maneira que está posto, podemos, se for interessante, imprimir em papéis maiores que o A4, mais comum, e a atividade não precisa sofrer alterações, desde que a ampliação mantenha a proporção.

Os alunos foram separados em grupos de no máximo três pessoas, e todos os grupos receberam régua, compasso e esquadro (não importa se é o de $60^{\circ}$ ou $45^{\circ}$ ). Os roteiros são distribuídos juntamente com dois mapas, e o professor deve ler o roteiro com os alunos e em cada pergunta, parar para discutir, instigar os alunos e fazer com que anotem suas respostas na parte 
apropriada do roteiro. Eles devem fazer anotações no caderno também, já que nem todos poderão levar os roteiros embora. É muito importante que o professor faça junto e anote as principais respostas na lousa, assim, durante as discussões os alunos, que tem apenas um roteiro por grupo, podem participar de forma mais presente nas discussões. Recomenda-se também ao docente que recolha as atividades ao término de cada aula e às devolva na próxima aplicação, isso para evitar dos alunos perderem roteiros e mapas prontos ou já trabalhados.

\subsubsection{Roteiro para os alunos}

\section{Sequência didática envolvendo Geometria e GPS}

\section{Estudo de caso: Investigação e perseguição.}

Jorge é investigador na cidade de São Carlos, região central do estado de São Paulo, e procura um vereador corrupto que se esconde na cidade. O Delegado o incumbiu dessa tarefa, e que fizesse sozinho, pois temia que outros investigadores tivessem ligação com o vereador e pudessem alertá-lo da investigação. Para localizar esse fora da lei ele deve rastrear o aparelho celular do político, utilizando o GPS (Global Position System, Sistema de Posicionamento Global na tradução livre).

Para que você possa ajudá-lo, responda as questões a seguir e reflita sobre seus conhecimentos sobre o assunto pensando no funcionamento do GPS do seu celular.

Sabemos que nosso celular, algumas vezes, perde o sinal, seja do GPS, do Wi-fi de casa ou até mesmo da rede telefônica.

1. Você saberia listar alguns dos motivos pelos quais nosso aparelho perde esses sinais?

2. Como você imagina que funcione o GPS?

3. Você já ficou sem sinal GPS? Se sim, em qual(is) situação(ões)?

Baseando-se nessas perguntas nosso investigador ficou imaginando quantos pontos de referência seriam necessários para localizar o investigado. "Será que bastaria saber a qual distância o criminoso se encontra de um ponto fixo? Como o "Balão do Bonde" na Vila Nery?

4. Quantos seriam os possíveis lugares para investigar, se soubermos que um sinal de celular do vereador foi medido entre $2500 \mathrm{~m}$ e $3000 \mathrm{~m}$ da torre localizada no centro do "Balão do Bonde" (Torre A)?

5. É possível fazer uma investigação eficiente e rápida com essa lista de locais?! 
6. Você saberia descrever a figura que formou após delimitarmos a área de investigação de Jorge?

Assim como você, o investigador percebeu que precisava de mais dados, e que apenas um ponto de referência não bastava, eram muitos locais para investigar e ficar de tocaia sozinho, pois o vereador poderia estar em um lugar na segunda-feira e em outro na terça, mesmo com os locais, de certa forma, delimitados. A investigação seria um desastre, e seu chefe ficaria furioso. Jorge precisava refinar sua investigação.

7. Quantos pontos de referência o investigador precisa para encontrar o fugitivo?

Responder essa questão corretamente faria com que Jorge fosse bem sucedido e que não trabalhasse muito também, porque se forem pontos de menos, não localizaria, mas se forem pontos de mais o trabalho será demais para uma só pessoa.

Pensando sobre o assunto, resolveu estudar o funcionamento do sistema GPS e constatou o seguinte: o GPS tem satélites espalhados ao redor de todo o mundo, todos equipados com transmissores e receptores, que funcionam tanto entre os satélites, quanto entre satélites e aparelhos na superfície terrestre, como aparelhos celulares, sistemas de navegação de navios, e outros tantos.

8. Você saberia dizer quais sistemas dependem do GPS nos tempos atuais?

9. Se o GPS saísse de funcionamento por 30 dias, quais setores seriam mais prejudicados?

Depois de ter estudado, Jorge percebeu que rastrear um celular pelo GPS seria complicado demais, teria que ter autorização do Juiz para entrar no sistema, e orientado pelo delegado, percebeu que os sistemas de telefonia trabalhavam aproximadamente como trabalham os satélites, mas com torres fixas na superfície da Terra. Como o intuito era apenas encontrar a localização aproximada do vereador, bastaria usar os dados da operadora de celular que o procurado usava. Com essa informação, o investigador foi logo buscar saber qual a operadora de celular do procurado, depois onde estão localizadas as torres dessa operadora, e então quantas informações poderiam ser coletadas dessas torres. Ficou sabendo que um celular pode funcionar conectado com mais de uma torre, e assim diminuir os locais de investigação.

Responder a questão número “7” corretamente faria com que a investigação fosse agilizada.

Entrando em contato com a operadora do fugitivo, Jorge conseguiu uma informação importantíssima, o celular estava conectado naquele momento à duas torres. Estava à $2 \mathrm{~km}$ da torre B e $1800 \mathrm{~m}$ da torre $\mathrm{C}$. 
10. Tente localizá-lo com esses dados.

11. A área de busca diminuiu?

12. Já é suficiente para o investigador encontrar o procurado?!

Com o desenvolvimento dos estudos sobre geometria, e lugares geométricos, que teve que acompanhar Jorge durante a investigação, ele percebeu que seria necessário mais um ponto de referência para a localização do corrupto.

Jorge precisou ir até a operadora e pegar o histórico de ligações do vereador, e quais eram as torres que ele utilizava. Tendo em mãos a capacidade de alcance de cada torre e o alcance do celular do vereador, conseguiu mapear sua rotina.

O mapa ${ }^{1}$ abaixo mostra a localização de cada torre de celular na cidade, e a tabela mostra o alcance de cada uma.

13. Utilizando o mapa, represente o alcance de cada torre, para ajudar nosso investigador.

Após isso feito, a tabela a seguir especifica a distância aproximada do celular até cada torre, em determinados dias da semana e horários correspondentes às ligações realizadas. Utilize os dados que julgar pertinentes para tentar localizar o vereador em sua rotina e, diminuindo os locais de investigação, responda:

14. Quando e onde é melhor para que o investigador tenha maiores chances de prender o vereador?

\begin{tabular}{cccccccccc}
\hline \multicolumn{8}{c}{ Torres e respectivas distâncias (em metros) } \\
\hline Dia & Hora & A & B & C & D & E & F & G & H \\
\hline Seg & $18 \mathrm{~h}$ & & & 2300 & & & & 2800 & \\
Ter & $22 \mathrm{~h}$ & 1800 & & & 2400 & 2500 & & & \\
Qua & $15 \mathrm{~h}$ & & & 2200 & & 1000 & & & \\
Qui & $08 \mathrm{~h}$ & 1800 & & & 2000 & & 1800 & & 2500 \\
Sex & $12 \mathrm{~h}$ & & 2000 & 3200 & & & & 2200 & \\
Sab & $9 \mathrm{~h}$ & & 1600 & 1500 & & & 1400 & & \\
\hline
\end{tabular}

Abaixo dados para a escala do mapa (podem usar qualquer uma dessas referências)

1 O mapa entregue é uma versão impressa em página cheia do mapa na Figura 10, p. 33. 


\begin{tabular}{cc}
\hline Torres Relacionadas & Distância entre elas (m) \\
\hline A-F & 1700 \\
A-C & 3050 \\
D-F & 2500 \\
B-F & 3000 \\
E-F & 2800 \\
\hline
\end{tabular}

Respostas

1.

2.

3.

4.

5.

6.

7. Espere para responder essa.

8.

9.

10. Foi possível a localização?

11.

12.

13. Utilize um dos mapas apenas para essa questão

14. Faça ao menos 4 representações de acordo com a tabela e interprete-as, diga se a investigação será fácil ou difícil e o porquê! 


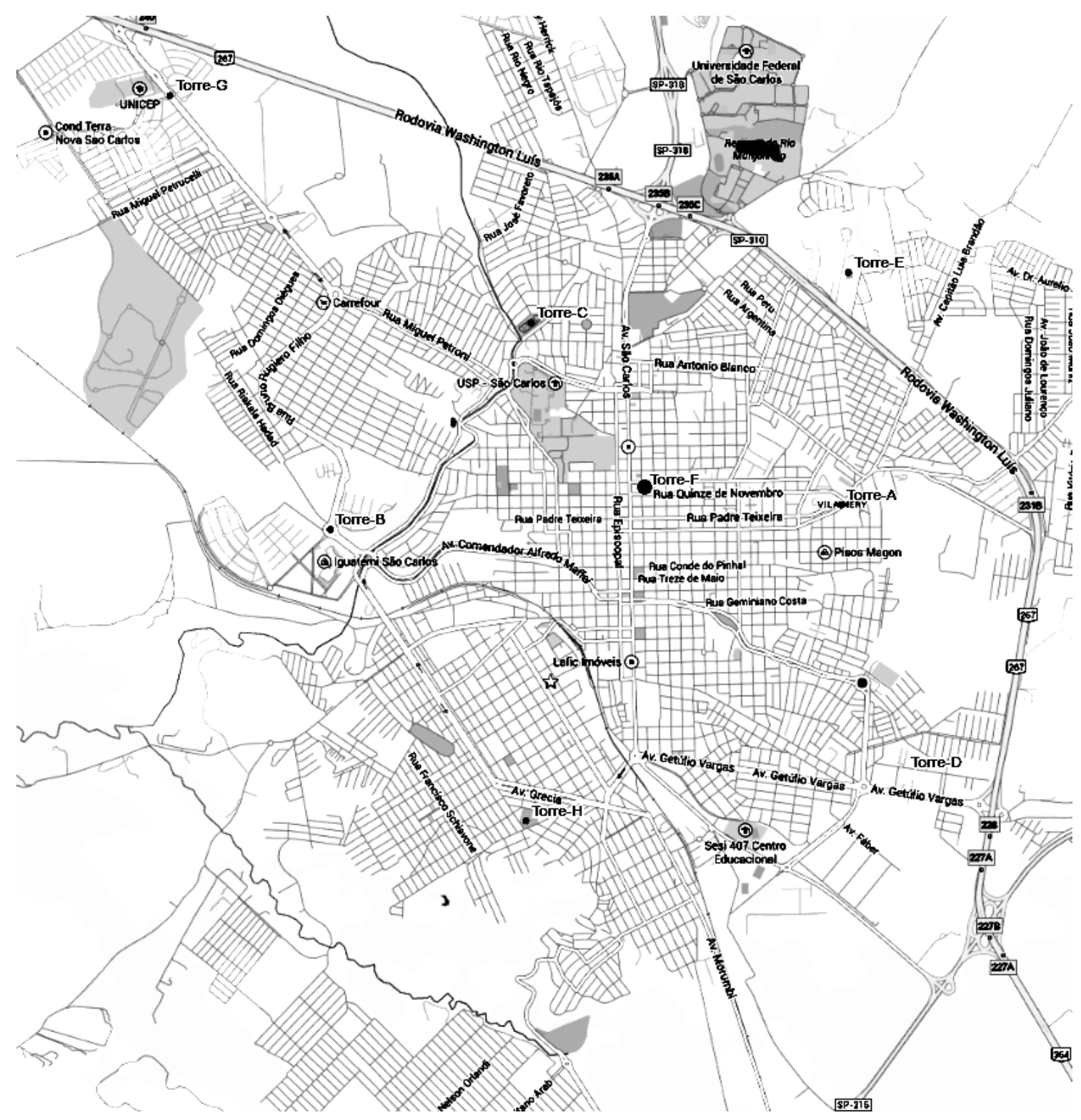

Figura 10 - Mapa fornecido aos aulos para o trabalho da atividade.

\subsubsection{Roteiro para o professor}

1. Comece falando sobre o GPS e tente instigar a curiosidade dos alunos.

a) Pergunte quem usa com frequência

b) Se teve alguma situação que o GPS foi útil.

c) Onde e quando perderam o Sinal GPS do celular.

2. Na pergunta 4 (se o sinal fosse detectado de $2500 \mathrm{~m}$ a $3000 \mathrm{~m}$...) use figuras geométricas diferentes da circunferência, para que os alunos sejam desafiados e cheguem a conclusão da circunferência por exclusão, ou por outro método.

a) Métodos e comentários 
3. Número de pontos de referência

a) Discuta com os alunos como poderíamos chegar e reduzir as áreas de busca.

i. Quantos pontos de referência seriam necessários?

ii. Esses pontos de referência podem ser de qualquer jeito?

- Mostre que colinearmente não são de grande valia.

4. Trabalhe com os alunos primeiramente as escalas, para que eles criem um GABARITO e facilite para eles quando forem utilizar o mapa.

\subsubsection{Segunda atividade feita por alguns alunos}

Nas figuras 11, 12 e 13 está exposta a execução de um dos alunos. Na Figura 11, vemos a folha de resposta preenchida. Na Figura 12, vê-se o trabalho com escalas usando desenho geométrico para se construir proporções. Finalmente, na Figura 13, vemos os mapas que o aluno utilizou para executar a atividade proposta com os mapas. 


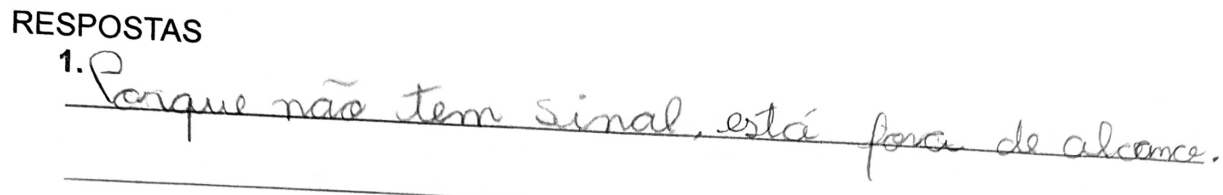

2.

Pela via sate léte

3.

Naro

porque en nà use o GPS

4.

5.

6. Naro

Vm cinculo dentirs de outuso

7. Espere para responder essa.

4 pontor de referencia

Motoristas profissionais, motoristas amadones, navios, avioes, Gubras

9. Dotouistas

10. Foi possivel a localização?

11.

12. Qten nofie

13. Utilize um dos mapas apenas para essa questão

14. Faça ao menos 4 representações de acordo com a tabela e interprete-as, diga se a investigação será fácil ou difícil e o porquê!

Figura 11 - Resposta ao questionário. 


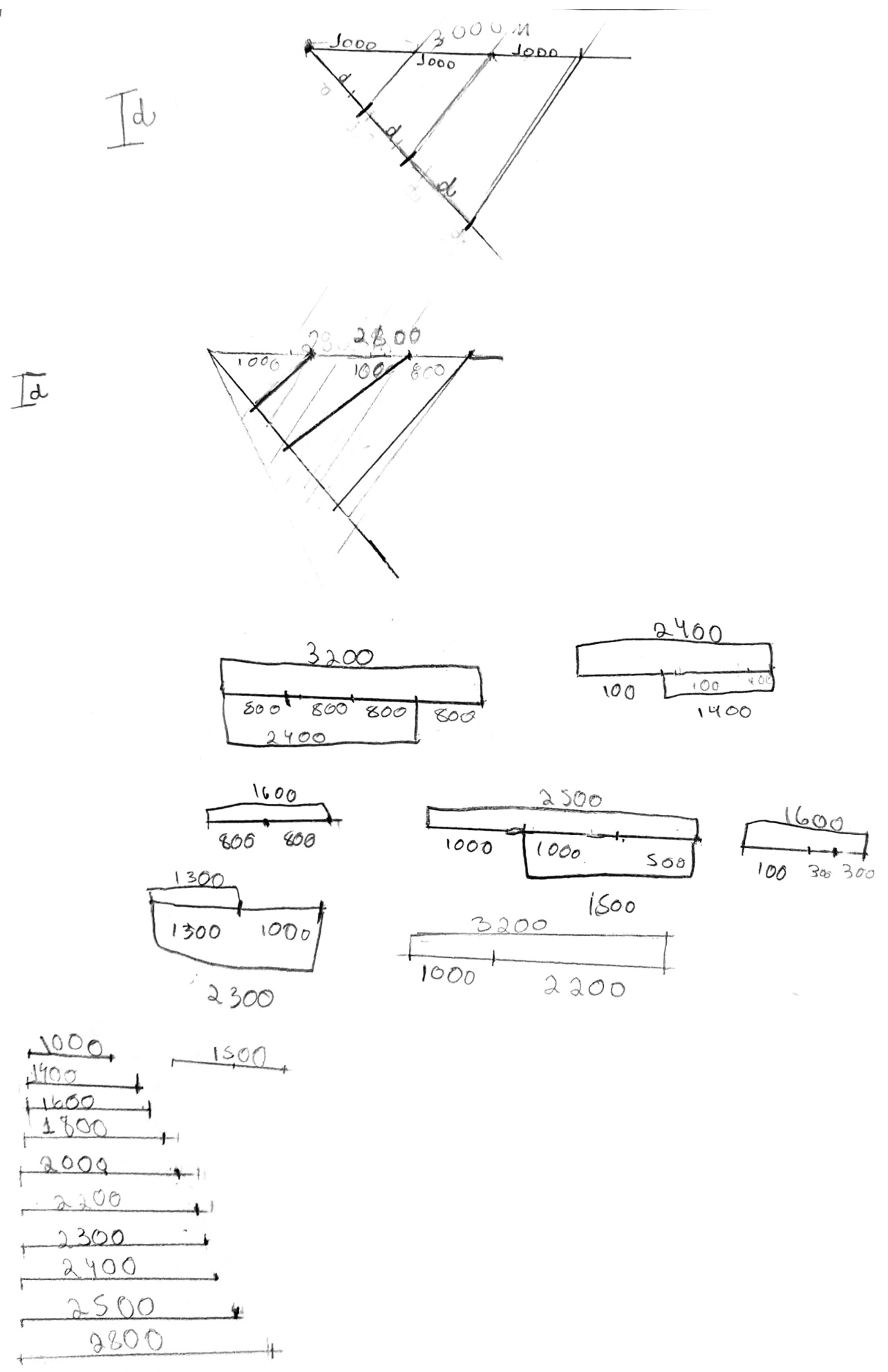

Figura 12 - Trabalho com escalas no mapa, fornecida apenas a distância de duas torres. 


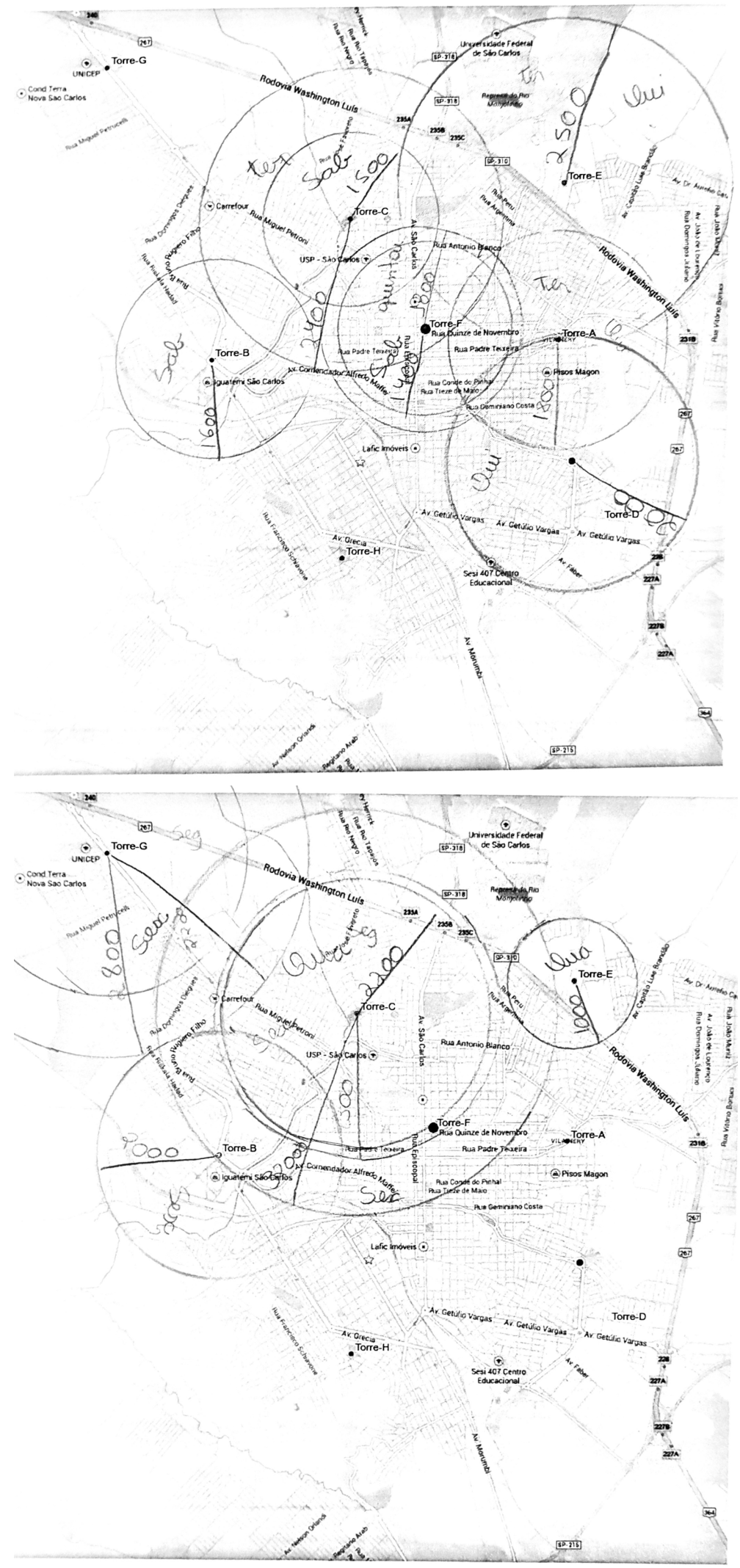

Figura 13 - Execução da atividade nos mapas. 


\subsection{Terceira proposta de atividades}

Esta terceira atividade foi elaborada para reunir todos os conceitos do GPS, mostrando a interdisciplinaridade dessa formidável aplicação. Nela, trabalha-se desde a montagem do sistema de equações de circunferências, que ao subtrairmos uma das equações, torna-se um sistema linear com as variáveis $x, y$ e $d$, sendo $d$ a distância incógnita ao primeiro ponto de referência. Tal sistema, ao ser resolvido, dá $x$ e $y$ como funções afins de $d$. Finalmente, ao substituirmos na primeira equação, obtemos uma equação quadrática em $d$, que ao ser resolvida (com uma ou duas soluções) nos permite substituir nas fórmulas para $x$ e $y$ e calculá-los.

Eis uma atividade, que pode ser já passada a alunos em sala de aula, ou realizada como exemplo pelo professor.

Um terreno tem torres nos pontos de coordenadas $A=(0,0), B=(1,20), C=(21,0)$, com unidades em metros. As torres emitem simultaneamente um sinal sonoro. Um observador, numa posição desconhecida, com um gravador eletrônico, observa o padrão de som seguinte

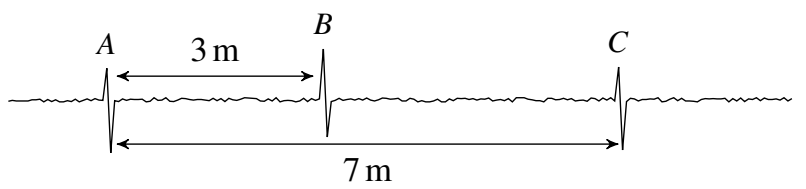

e conclui que sua distância respectivamente às torres $B$ e $C$ excedem em $3 \mathrm{~m}$ e $7 \mathrm{~m}$ sua distância à torre $A$. Calcule a posição do observador.

\subsubsection{Solução algébrica}

O sistema a ser montado é $A=(0,0), B=(1,20), C=(21,0), P=(x, y)$. As distâncias de $P$ aos pontos de referência nos dão as equações

$$
\left\{\begin{array}{l}
P A=d \\
P B=d+3 \\
P C=d+7
\end{array}\right.
$$

que se desenvolvem nas equações

$$
\left\{\begin{array}{l}
x^{2}+y^{2}=d^{2} \\
(x-1)^{2}+(y-20)^{2}=(d+3)^{2} \\
(x-21)^{2}+y^{2}=(d+7)^{2}
\end{array}\right.
$$

Desenvolvendo o sistema acima, subtraindo a primeira linha das outras duas teremos o sistema linear

$$
\left\{\begin{array}{l}
x-20 y=3 d-196 \\
3 x=-d+28
\end{array}\right.
$$


Isolando $x$ e $y$ no sistema acima, teremos as coordenadas de $P$ em função de $d$ da seguinte maneira:

$$
P=\left(\frac{-d+28}{3}, \frac{-2 d+140}{15}\right)
$$

Substituindo as expressões de $x$ e $y$ na primeira equação do sistema quadrático, temos a sequência de equações equivalentes:

$$
\begin{gathered}
\left(\frac{-d+28}{3}\right)^{2}+\left(\frac{-2 d+140}{15}\right)^{2}=d^{2} \\
\frac{d^{2}-56 d+784}{9}+\frac{4 d^{2}-560+19600}{225}=d^{2} \\
\frac{25 d^{2}-1400 d+19600+4 d^{2}-560+19600}{225}=\frac{225 d^{2}}{225} \\
196 d^{2}+1960 d-39200=0 \\
d^{2}+10 d-200=0 \Longrightarrow d=10 \text { ou } d=-20
\end{gathered}
$$

Substituindo $d=10$ nas expressões de $x$ e $y$, obtemos $x=6, y=8$ e, portanto, $P=(6,8)$.

\subsubsection{Solução geométrica}

O mesmo problema pode ser resolvido geometricamente com hipérboles, utilizando um software de geometria dinâmica como o Geogebra. Os passos para a resolução são imediatos, bastando seguir os seguintes comandos:

- Na caixa de entrada, defina os pontos escrevendo os comandos abaixo, seguidos da tecla Enter:

$$
\begin{aligned}
& A=(0,0) \\
& B=(1,20) \\
& C=(21,0)
\end{aligned}
$$

- Agora, ao digitar Hipérbole na caixa de comando, a ajuda do programa sugere três parâmetros

\section{Hipérbole( Foco, Foco, Comprimento do semieixo maior)}

Na hipérbole $P B-P A=3$, o semieixo maior mede $\frac{3}{2}$, e na hipérbole $P C-P A=7$, o semieixo maior mede $\frac{7}{2}$.

- Assim, na caixa de entrada, escreva

$$
\begin{aligned}
& \text { alpha_1 : Hipérbole(A, B, 3/2) } \\
& \text { alpha_2 : Hipérbole(A, C, 7/2) }
\end{aligned}
$$




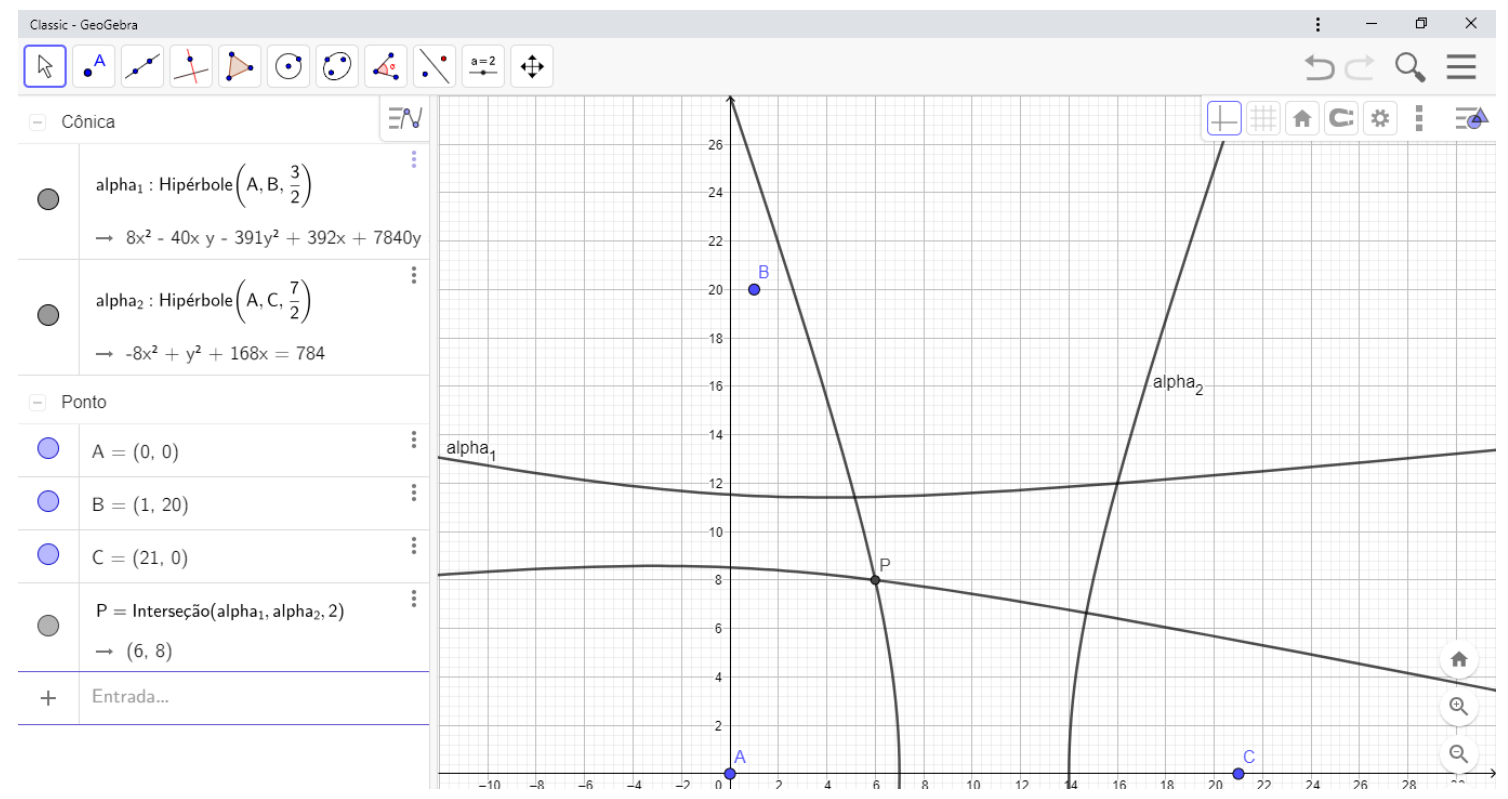

Figura 14 - Resolução geométrica do exemplo usando o Geogebra. A solução $P$ está na interseção dos ramos das hipérboles $\alpha_{1}: P B-P A=3$ e $\alpha_{2}: P C-P A=7$ mais próximos de $A$.

Mas esses comandos traçam dois ramos de hipérbole cada, havendo várias interseções. Visualmente, apenas uma delas está nos ramos mais próximos de $A$. Esta é a solução $P$

- Com a ferramenta Ponto, clique na interseção em $P$ (renomeando o ponto para $P$ se necessário). Na janela de objetos, aparecerá a solução do problema. Veja a captura de tela do programa na Figura 14

\subsubsection{Elaboração da atividade}

Com respeito à elaboração da atividade, para facilitar ao máximo, a fim de que as respostas fossem inteiras com números inteiros no enunciado, na sua elaboração utilizamos ternas pitagóricas para obter triângulos retângulos com lados inteiros, como se pode ver na Figura 15.

\subsubsection{Mais um exercício}

Na mesma linha do exemplo resolvido anteriormente, propomos o seguinte exercício: 


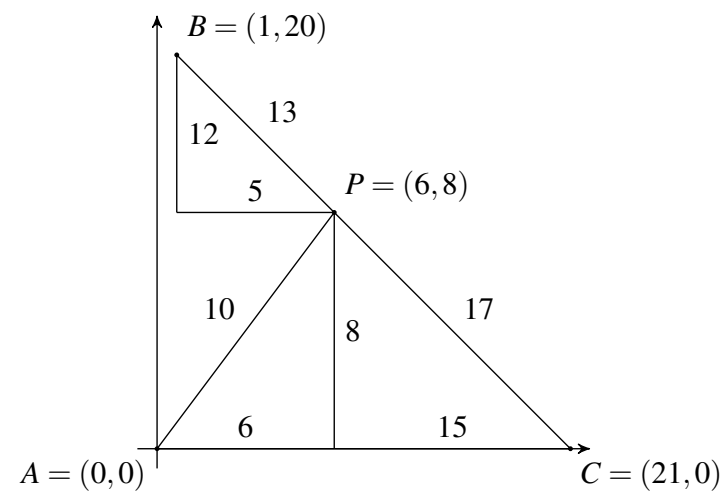

Figura 15 - Elaboração do exemplo feito em sala de aula, a partir das ternas pitagóricas $(5,12,13)$, $(6,8,10)$ e $(8,15,17)$. A solução é $P=(6,8)$.

Um terreno tem torres nos pontos de coordenadas $A=(0,0), B=(25,0), C=(0,52)$, com unidades em metros. As torres emitem simultaneamente um sinal sonoro. Um observador, numa posição desconhecida, com um gravador eletrônico, observa o padrão de som seguinte

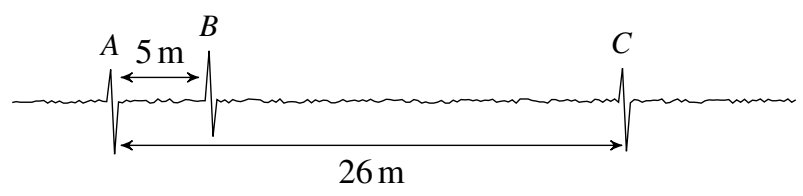

e conclui que suas distâncias às torres $B$ e $C$ excedem em $5 \mathrm{~m}$ e $26 \mathrm{~m}$ sua distância à torre $A$. Calcule a posição do observador. 

Espero que essa prática encontre professores motivados e alunos interessados em descobrir como a matemática pode ser útil e bonita ao mesmo tempo. Os alunos que tiveram contato, através de minhas aulas me ensinaram muito, com questionamentos para que eu pudesse aprimorar a prática e adequar a atividade à realidade da escola, tentando trabalhar com o mínimo recurso de mídia, pois sei que as escolas nem sempre tem à disposição do professor uma sala de vídeo, ou de informática. Tentei também fazer um trabalho que facilite a vida dos colegas e traga significação para aqueles que encontram na Matemática e na Geometria pouca inspiração, a pesar de saberem que sem o desenvolvimento dessa Ciência não seria possível atingirmos o conforto que temos hoje, seja de um banho quente, ou de um copo de água refrigerado. Empatia com o professor, significação e motivação são quesitos que promovem um processo de ensino aprendizagem significativo, não são talvez, suficientes, mas produzem um bom alicerce para que a formação seja a mais integral possível, formando jovens como o Estado e o mercado exigem, Autônomos, Solidários e Competentes (Programa de Ensino Integral - São Paulo). 



\section{MATERIAIS UTILIZADOS NAS ATIVIDADES DESENVOLVIDAS EM SALA DE AULA}

Na primeira proposta de atividades, explanada na Seção 2.1, utilizamos como material um mapa e uma folha de enunciado distinta para cada aluno. Incluiremos aqui o mapa de São Carlos - que sugerimos que sejam dados três cópias para cada aluno - e dez folhas de enunciado.

A confecção do mapa foi feita por sobreposição de imagems a partir de capturas de tela se sites de mapas, como o Google Mapas.

Na segunda proposta, os enunciados encontram-se nas seções 2.2.1 e 2.2.2, pp. 29 e 33, e o mapa encontra-se na Figura 10, p. 33.

Para a terceira, enunciados dessas atividades encontram-se nas seções 2.3 e 2.3.4, pp. 38 e 40 . 


\section{SÃO CARLOS - Mapa da região central}

Escala: $1: 30.000 \quad(1 \mathrm{~cm}$ no mapa $=300 \mathrm{~m})$

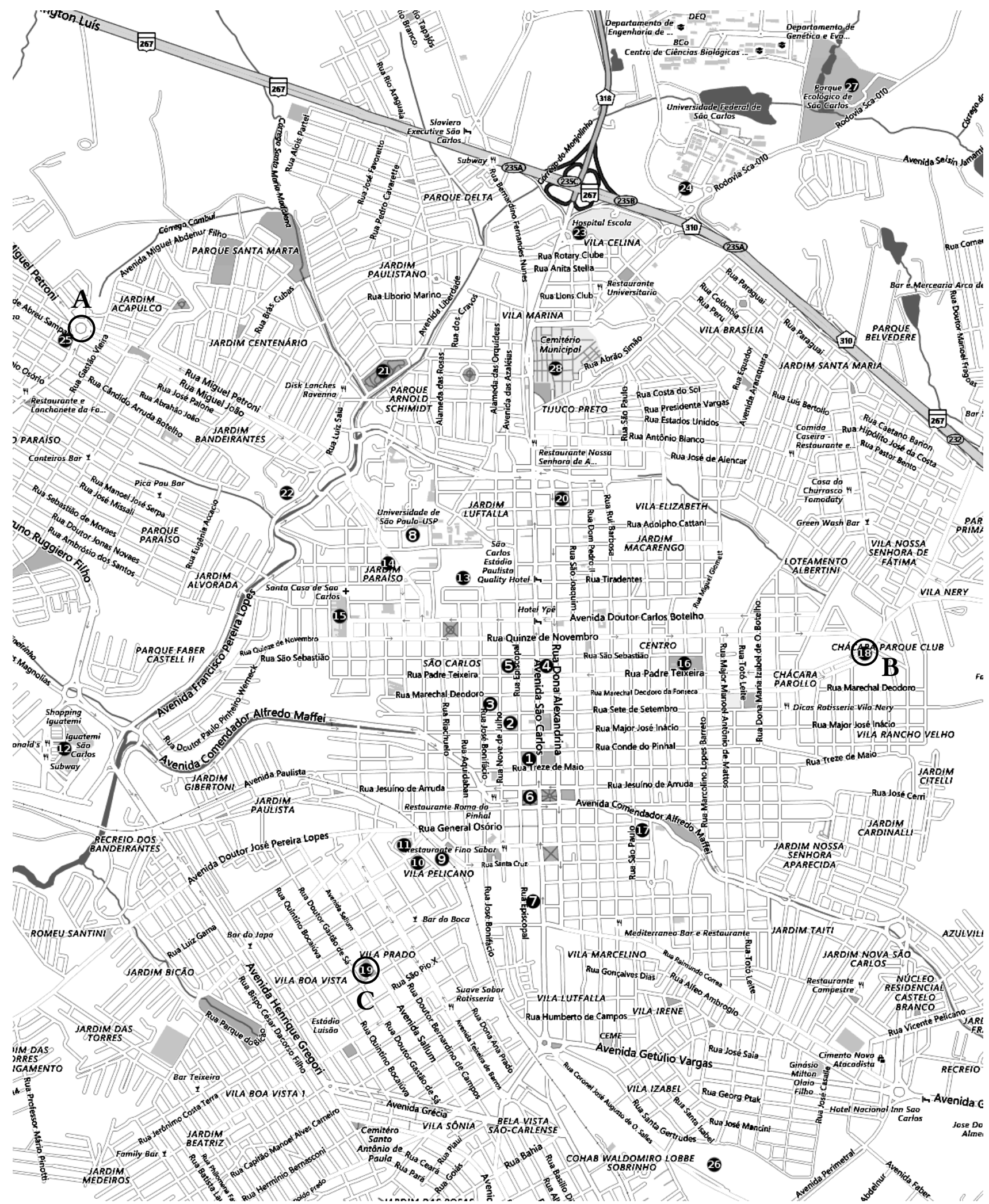

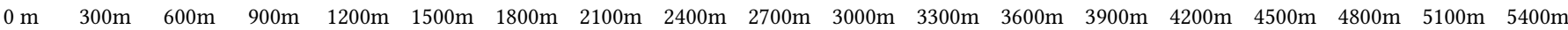

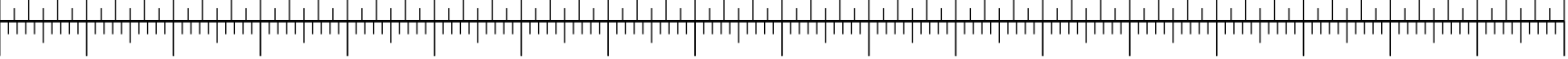

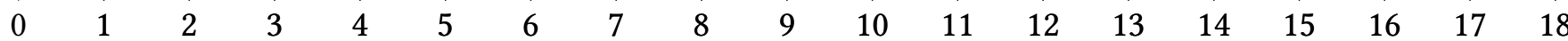




\section{Atividade GPS: triangulação}

Tomando pontos de referência:

A - Rotatória do Carrefour (Santa Felícia)

B - Balão do bonde da Vila Nery

C - Igreja Santo Antônio (Vila Prado)

1) Você é capaz de dizer o que se encontra nos locais abaixo, dadas as distâncias aos pontos A, B e C?

\begin{tabular}{cccc}
\hline Local & Até A $(\mathrm{m})$ & Até B $(\mathrm{m})$ & Até C $(\mathrm{m})$ \\
\hline $1^{\circ}$ & 3550 & 1990 & 1300 \\
$2^{\circ}$ & 2790 & 1860 & 2790 \\
$3^{\circ}$ & 2870 & 2770 & 4260 \\
$4^{\circ}$ & 3500 & 2570 & 740 \\
$5^{\circ}$ & 3400 & 1920 & 1450 \\
\hline
\end{tabular}

2) Escolha alguns pontos do mapa e calcule as distâncias deles aos pontos de referência.

\begin{tabular}{llll}
\hline Local & Até A $(\mathrm{m})$ & Até B $(\mathrm{m})$ & Até C $(\mathrm{m})$ \\
\hline $1^{\mathrm{o}}$ & & \\
\hline $2^{\mathrm{o}}$ & & \\
\hline $3^{\circ}$ & & \\
\hline $4^{\circ}$ & & \\
\hline
\end{tabular}

\section{Locais assinalados no mapa}

1. Catedral de São Carlos

2. Prefeitura

3. Teatro municipal

4. Álvaro Guião

5. Colégio São Carlos

6. Mercado municipal

7. Senac

8. Universidade de São Paulo - USP

9. Estação Ferroviária

10. Senai

11. Poupa-Tempo

12. Shopping Iguatemi

13. São Carlos Club

14. Igreja N. Sra. Fátima e Livraria Querigma
15. Santa Casa

16. Campo do Rui

17. Forum

18. Balão do Bonde da Vila Nery

19. Igreja Santo Antônio (Vila Prado)

20. Rodoviária

21. Kartódromo

22. Shopping Passeio São Carlos

23. Hospital-Escola

24. Universidade Federal de São Carlos

25. Carrefour (Santa Felícia)

26. Sesi

27. Parque Ecológico

28. Cemitério N. Sra. do Carmo 


\section{Atividade GPS: triangulação}

Tomando pontos de referência:

A - Rotatória do Carrefour (Santa Felícia)

B - Balão do bonde da Vila Nery

C - Igreja Santo Antônio (Vila Prado)

1) Você é capaz de dizer o que se encontra nos locais abaixo, dadas as distâncias aos pontos A, B e C?

\begin{tabular}{cccc}
\hline Local & Até A $(\mathrm{m})$ & Até B $(\mathrm{m})$ & Até C $(\mathrm{m})$ \\
\hline $1^{\mathrm{o}}$ & 1660 & 3060 & 3260 \\
$2^{\text {o }}$ & 2120 & 2880 & 1940 \\
$3^{\text {o }}$ & 3500 & 2570 & 740 \\
$4^{\text {o }}$ & 3400 & 1920 & 1450 \\
$5^{\text {o }}$ & 3330 & 2720 & 720 \\
\hline
\end{tabular}

2) Escolha alguns pontos do mapa e calcule as distâncias deles aos pontos de referência.

\begin{tabular}{llll}
\hline Local & Até A $(\mathrm{m})$ & Até B $(\mathrm{m})$ & Até C $(\mathrm{m})$ \\
\hline $1^{\mathrm{o}}$ & & \\
\hline $2^{\mathrm{o}}$ & & \\
\hline $3^{\circ}$ & & \\
\hline $4^{\circ}$ & & \\
\hline
\end{tabular}

\section{Locais assinalados no mapa}

1. Catedral de São Carlos

2. Prefeitura

3. Teatro municipal

4. Álvaro Guião

5. Colégio São Carlos

6. Mercado municipal

7. Senac

8. Universidade de São Paulo - USP

9. Estação Ferroviária

10. Senai

11. Poupa-Tempo

12. Shopping Iguatemi

13. São Carlos Club

14. Igreja N. Sra. Fátima e Livraria Querigma
15. Santa Casa

16. Campo do Rui

17. Forum

18. Balão do Bonde da Vila Nery

19. Igreja Santo Antônio (Vila Prado)

20. Rodoviária

21. Kartódromo

22. Shopping Passeio São Carlos

23. Hospital-Escola

24. Universidade Federal de São Carlos

25. Carrefour (Santa Felícia)

26. Sesi

27. Parque Ecológico

28. Cemitério N. Sra. do Carmo 


\section{Atividade GPS: triangulação}

Tomando pontos de referência:

A - Rotatória do Carrefour (Santa Felícia)

B - Balão do bonde da Vila Nery

C - Igreja Santo Antônio (Vila Prado)

1) Você é capaz de dizer o que se encontra nos locais abaixo, dadas as distâncias aos pontos A, B e C?

\begin{tabular}{cccc}
\hline Local & Até A $(\mathrm{m})$ & Até B $(\mathrm{m})$ & Até C $(\mathrm{m})$ \\
\hline $1^{\circ}$ & 3400 & 1920 & 1450 \\
$2^{\circ}$ & 3500 & 2570 & 740 \\
$3^{\circ}$ & 1660 & 3060 & 3260 \\
$4^{\text {o }}$ & 3330 & 2720 & 720 \\
$5^{\circ}$ & 2120 & 2650 & 2230 \\
\hline
\end{tabular}

2) Escolha alguns pontos do mapa e calcule as distâncias deles aos pontos de referência.

\begin{tabular}{llll}
\hline Local & Até A $(\mathrm{m})$ & Até B $(\mathrm{m})$ & Até C $(\mathrm{m})$ \\
\hline $1^{\mathrm{o}}$ & & \\
\hline $2^{\mathrm{o}}$ & & \\
\hline $3^{\circ}$ & & \\
\hline $4^{\circ}$ & & \\
\hline
\end{tabular}

\section{Locais assinalados no mapa}

1. Catedral de São Carlos

2. Prefeitura

3. Teatro municipal

4. Álvaro Guião

5. Colégio São Carlos

6. Mercado municipal

7. Senac

8. Universidade de São Paulo - USP

9. Estação Ferroviária

10. Senai

11. Poupa-Tempo

12. Shopping Iguatemi

13. São Carlos Club

14. Igreja N. Sra. Fátima e Livraria Querigma
15. Santa Casa

16. Campo do Rui

17. Forum

18. Balão do Bonde da Vila Nery

19. Igreja Santo Antônio (Vila Prado)

20. Rodoviária

21. Kartódromo

22. Shopping Passeio São Carlos

23. Hospital-Escola

24. Universidade Federal de São Carlos

25. Carrefour (Santa Felícia)

26. Sesi

27. Parque Ecológico

28. Cemitério N. Sra. do Carmo 


\section{Atividade GPS: triangulação}

Tomando pontos de referência:

A - Rotatória do Carrefour (Santa Felícia)

B - Balão do bonde da Vila Nery

C - Igreja Santo Antônio (Vila Prado)

1) Você é capaz de dizer o que se encontra nos locais abaixo, dadas as distâncias aos pontos A, B e C?

\begin{tabular}{cccc}
\hline Local & Até A $(\mathrm{m})$ & Até B $(\mathrm{m})$ & Até C $(\mathrm{m})$ \\
\hline $1^{\mathrm{o}}$ & 3400 & 1920 & 1450 \\
$2^{\text {o }}$ & 3500 & 2570 & 740 \\
$3^{\text {o }}$ & 1660 & 3060 & 3260 \\
$4^{\text {o }}$ & 2120 & 2880 & 1940 \\
$5^{\text {o }}$ & 3330 & 2720 & 720 \\
\hline
\end{tabular}

2) Escolha alguns pontos do mapa e calcule as distâncias deles aos pontos de referência.

\begin{tabular}{llll}
\hline Local & Até A $(\mathrm{m})$ & Até B $(\mathrm{m})$ & Até C $(\mathrm{m})$ \\
\hline $1^{\mathrm{o}}$ & & \\
\hline $2^{\mathrm{o}}$ & & \\
\hline $3^{\circ}$ & & \\
\hline $4^{\circ}$ & & \\
\hline
\end{tabular}

\section{Locais assinalados no mapa}

1. Catedral de São Carlos

2. Prefeitura

3. Teatro municipal

4. Álvaro Guião

5. Colégio São Carlos

6. Mercado municipal

7. Senac

8. Universidade de São Paulo - USP

9. Estação Ferroviária

10. Senai

11. Poupa-Tempo

12. Shopping Iguatemi

13. São Carlos Club

14. Igreja N. Sra. Fátima e Livraria Querigma
15. Santa Casa

16. Campo do Rui

17. Forum

18. Balão do Bonde da Vila Nery

19. Igreja Santo Antônio (Vila Prado)

20. Rodoviária

21. Kartódromo

22. Shopping Passeio São Carlos

23. Hospital-Escola

24. Universidade Federal de São Carlos

25. Carrefour (Santa Felícia)

26. Sesi

27. Parque Ecológico

28. Cemitério N. Sra. do Carmo 


\section{Atividade GPS: triangulação}

Tomando pontos de referência:

A - Rotatória do Carrefour (Santa Felícia)

B - Balão do bonde da Vila Nery

C - Igreja Santo Antônio (Vila Prado)

1) Você é capaz de dizer o que se encontra nos locais abaixo, dadas as distâncias aos pontos A, B e C?

\begin{tabular}{cccc}
\hline Local & Até A $(\mathrm{m})$ & Até B $(\mathrm{m})$ & Até C $(\mathrm{m})$ \\
\hline $1^{\circ}$ & 3330 & 2720 & 720 \\
$2^{\circ}$ & 3400 & 1920 & 1450 \\
$3^{\circ}$ & 2120 & 2880 & 1940 \\
$4^{\text {o }}$ & 3550 & 1990 & 1300 \\
$5^{\circ}$ & 2870 & 2770 & 4260 \\
\hline
\end{tabular}

2) Escolha alguns pontos do mapa e calcule as distâncias deles aos pontos de referência.

\begin{tabular}{llll}
\hline Local & Até A $(\mathrm{m})$ & Até B $(\mathrm{m})$ & Até C $(\mathrm{m})$ \\
\hline $1^{\mathrm{o}}$ & & \\
\hline $2^{\mathrm{o}}$ & & \\
\hline $3^{\circ}$ & & \\
\hline $4^{\circ}$ & & \\
\hline
\end{tabular}

\section{Locais assinalados no mapa}

1. Catedral de São Carlos

2. Prefeitura

3. Teatro municipal

4. Álvaro Guião

5. Colégio São Carlos

6. Mercado municipal

7. Senac

8. Universidade de São Paulo - USP

9. Estação Ferroviária

10. Senai

11. Poupa-Tempo

12. Shopping Iguatemi

13. São Carlos Club

14. Igreja N. Sra. Fátima e Livraria Querigma
15. Santa Casa

16. Campo do Rui

17. Forum

18. Balão do Bonde da Vila Nery

19. Igreja Santo Antônio (Vila Prado)

20. Rodoviária

21. Kartódromo

22. Shopping Passeio São Carlos

23. Hospital-Escola

24. Universidade Federal de São Carlos

25. Carrefour (Santa Felícia)

26. Sesi

27. Parque Ecológico

28. Cemitério N. Sra. do Carmo 


\section{Atividade GPS: triangulação}

Tomando pontos de referência:

A - Rotatória do Carrefour (Santa Felícia)

B - Balão do bonde da Vila Nery

C - Igreja Santo Antônio (Vila Prado)

1) Você é capaz de dizer o que se encontra nos locais abaixo, dadas as distâncias aos pontos A, B e C?

\begin{tabular}{cccc}
\hline Local & Até A $(\mathrm{m})$ & Até B $(\mathrm{m})$ & Até C $(\mathrm{m})$ \\
\hline $1^{\circ}$ & 3500 & 2570 & 740 \\
$2^{\circ}$ & 3330 & 2720 & 720 \\
$3^{\circ}$ & 2120 & 2880 & 1940 \\
$4^{\text {o }}$ & 2790 & 1860 & 2790 \\
$5^{\circ}$ & 2870 & 2770 & 4260 \\
\hline
\end{tabular}

2) Escolha alguns pontos do mapa e calcule as distâncias deles aos pontos de referência.

\begin{tabular}{llll}
\hline Local & Até A $(\mathrm{m})$ & Até B $(\mathrm{m})$ & Até C $(\mathrm{m})$ \\
\hline $1^{\mathrm{o}}$ & & \\
\hline $2^{\mathrm{o}}$ & & \\
\hline $3^{\circ}$ & & \\
\hline $4^{\circ}$ & & \\
\hline
\end{tabular}

\section{Locais assinalados no mapa}

1. Catedral de São Carlos

2. Prefeitura

3. Teatro municipal

4. Álvaro Guião

5. Colégio São Carlos

6. Mercado municipal

7. Senac

8. Universidade de São Paulo - USP

9. Estação Ferroviária

10. Senai

11. Poupa-Tempo

12. Shopping Iguatemi

13. São Carlos Club

14. Igreja N. Sra. Fátima e Livraria Querigma
15. Santa Casa

16. Campo do Rui

17. Forum

18. Balão do Bonde da Vila Nery

19. Igreja Santo Antônio (Vila Prado)

20. Rodoviária

21. Kartódromo

22. Shopping Passeio São Carlos

23. Hospital-Escola

24. Universidade Federal de São Carlos

25. Carrefour (Santa Felícia)

26. Sesi

27. Parque Ecológico

28. Cemitério N. Sra. do Carmo 


\section{Atividade GPS: triangulação}

Tomando pontos de referência:

A - Rotatória do Carrefour (Santa Felícia)

B - Balão do bonde da Vila Nery

C - Igreja Santo Antônio (Vila Prado)

1) Você é capaz de dizer o que se encontra nos locais abaixo, dadas as distâncias aos pontos A, B e C?

\begin{tabular}{cccc}
\hline Local & Até A $(\mathrm{m})$ & Até B $(\mathrm{m})$ & Até C $(\mathrm{m})$ \\
\hline $1^{\circ}$ & 3500 & 2570 & 740 \\
$2^{\circ}$ & 2120 & 2650 & 2230 \\
$3^{\circ}$ & 2870 & 2770 & 4260 \\
$4^{\circ}$ & 3330 & 2720 & 720 \\
$5^{\circ}$ & 3200 & 1960 & 1560 \\
\hline
\end{tabular}

2) Escolha alguns pontos do mapa e calcule as distâncias deles aos pontos de referência.

\begin{tabular}{llll}
\hline Local & Até A $(\mathrm{m})$ & Até B $(\mathrm{m})$ & Até C $(\mathrm{m})$ \\
\hline $1^{\mathrm{o}}$ & & \\
\hline $2^{\mathrm{o}}$ & & \\
\hline $3^{\circ}$ & & \\
\hline $4^{\circ}$ & & \\
\hline
\end{tabular}

\section{Locais assinalados no mapa}

1. Catedral de São Carlos

2. Prefeitura

3. Teatro municipal

4. Álvaro Guião

5. Colégio São Carlos

6. Mercado municipal

7. Senac

8. Universidade de São Paulo - USP

9. Estação Ferroviária

10. Senai

11. Poupa-Tempo

12. Shopping Iguatemi

13. São Carlos Club

14. Igreja N. Sra. Fátima e Livraria Querigma
15. Santa Casa

16. Campo do Rui

17. Forum

18. Balão do Bonde da Vila Nery

19. Igreja Santo Antônio (Vila Prado)

20. Rodoviária

21. Kartódromo

22. Shopping Passeio São Carlos

23. Hospital-Escola

24. Universidade Federal de São Carlos

25. Carrefour (Santa Felícia)

26. Sesi

27. Parque Ecológico

28. Cemitério N. Sra. do Carmo 


\section{Atividade GPS: triangulação}

Tomando pontos de referência:

A - Rotatória do Carrefour (Santa Felícia)

B - Balão do bonde da Vila Nery

C - Igreja Santo Antônio (Vila Prado)

1) Você é capaz de dizer o que se encontra nos locais abaixo, dadas as distâncias aos pontos A, B e C?

\begin{tabular}{cccc}
\hline Local & Até A $(\mathrm{m})$ & Até B $(\mathrm{m})$ & Até C $(\mathrm{m})$ \\
\hline $1^{\circ}$ & 3330 & 2720 & 720 \\
$2^{\circ}$ & 3500 & 2570 & 740 \\
$3^{\circ}$ & 3200 & 1960 & 1560 \\
$4^{\circ}$ & 2870 & 2770 & 4260 \\
$5^{\circ}$ & 3400 & 1920 & 1450 \\
\hline
\end{tabular}

2) Escolha alguns pontos do mapa e calcule as distâncias deles aos pontos de referência.

\begin{tabular}{llll}
\hline Local & Até A $(\mathrm{m})$ & Até B $(\mathrm{m})$ & Até C $(\mathrm{m})$ \\
\hline $1^{\mathrm{o}}$ & & \\
\hline $2^{\mathrm{o}}$ & & \\
\hline $3^{\circ}$ & & \\
\hline $4^{\circ}$ & & \\
\hline
\end{tabular}

\section{Locais assinalados no mapa}

1. Catedral de São Carlos

2. Prefeitura

3. Teatro municipal

4. Álvaro Guião

5. Colégio São Carlos

6. Mercado municipal

7. Senac

8. Universidade de São Paulo - USP

9. Estação Ferroviária

10. Senai

11. Poupa-Tempo

12. Shopping Iguatemi

13. São Carlos Club

14. Igreja N. Sra. Fátima e Livraria Querigma
15. Santa Casa

16. Campo do Rui

17. Forum

18. Balão do Bonde da Vila Nery

19. Igreja Santo Antônio (Vila Prado)

20. Rodoviária

21. Kartódromo

22. Shopping Passeio São Carlos

23. Hospital-Escola

24. Universidade Federal de São Carlos

25. Carrefour (Santa Felícia)

26. Sesi

27. Parque Ecológico

28. Cemitério N. Sra. do Carmo 


\section{Atividade GPS: triangulação}

Tomando pontos de referência:

A - Rotatória do Carrefour (Santa Felícia)

B - Balão do bonde da Vila Nery

C - Igreja Santo Antônio (Vila Prado)

1) Você é capaz de dizer o que se encontra nos locais abaixo, dadas as distâncias aos pontos A, B e C?

\begin{tabular}{cccc}
\hline Local & Até A $(\mathrm{m})$ & Até B $(\mathrm{m})$ & Até C $(\mathrm{m})$ \\
\hline $1^{\circ}$ & 1660 & 3060 & 3260 \\
$2^{\circ}$ & 3550 & 1990 & 1300 \\
$3^{\circ}$ & 3330 & 2720 & 720 \\
$4^{\text {o }}$ & 3200 & 1960 & 1560 \\
$5^{\circ}$ & 3400 & 1920 & 1450 \\
\hline
\end{tabular}

2) Escolha alguns pontos do mapa e calcule as distâncias deles aos pontos de referência.

\begin{tabular}{llll}
\hline Local & Até A $(\mathrm{m})$ & Até B $(\mathrm{m})$ & Até C $(\mathrm{m})$ \\
\hline $1^{\mathrm{o}}$ & & \\
\hline $2^{\mathrm{o}}$ & & \\
\hline $3^{\circ}$ & & \\
\hline $4^{\circ}$ & & \\
\hline
\end{tabular}

\section{Locais assinalados no mapa}

1. Catedral de São Carlos

2. Prefeitura

3. Teatro municipal

4. Álvaro Guião

5. Colégio São Carlos

6. Mercado municipal

7. Senac

8. Universidade de São Paulo - USP

9. Estação Ferroviária

10. Senai

11. Poupa-Tempo

12. Shopping Iguatemi

13. São Carlos Club

14. Igreja N. Sra. Fátima e Livraria Querigma
15. Santa Casa

16. Campo do Rui

17. Forum

18. Balão do Bonde da Vila Nery

19. Igreja Santo Antônio (Vila Prado)

20. Rodoviária

21. Kartódromo

22. Shopping Passeio São Carlos

23. Hospital-Escola

24. Universidade Federal de São Carlos

25. Carrefour (Santa Felícia)

26. Sesi

27. Parque Ecológico

28. Cemitério N. Sra. do Carmo 


\section{Atividade GPS: triangulação}

Tomando pontos de referência:

A - Rotatória do Carrefour (Santa Felícia)

B - Balão do bonde da Vila Nery

C - Igreja Santo Antônio (Vila Prado)

1) Você é capaz de dizer o que se encontra nos locais abaixo, dadas as distâncias aos pontos A, B e C?

\begin{tabular}{cccc}
\hline Local & Até A $(\mathrm{m})$ & Até B $(\mathrm{m})$ & Até C $(\mathrm{m})$ \\
\hline $1^{\circ}$ & 2120 & 2880 & 1940 \\
$2^{\circ}$ & 2120 & 2650 & 2230 \\
$3^{\circ}$ & 2870 & 2770 & 4260 \\
$4^{\circ}$ & 3500 & 2570 & 740 \\
$5^{\circ}$ & 2790 & 1860 & 2790 \\
\hline
\end{tabular}

2) Escolha alguns pontos do mapa e calcule as distâncias deles aos pontos de referência.

\begin{tabular}{llll}
\hline Local & Até A $(\mathrm{m})$ & Até B $(\mathrm{m})$ & Até C $(\mathrm{m})$ \\
\hline $1^{\mathrm{o}}$ & & \\
\hline $2^{\mathrm{o}}$ & & \\
\hline $3^{\circ}$ & & \\
\hline $4^{\circ}$ & & \\
\hline
\end{tabular}

\section{Locais assinalados no mapa}

1. Catedral de São Carlos

2. Prefeitura

3. Teatro municipal

4. Álvaro Guião

5. Colégio São Carlos

6. Mercado municipal

7. Senac

8. Universidade de São Paulo - USP

9. Estação Ferroviária

10. Senai

11. Poupa-Tempo

12. Shopping Iguatemi

13. São Carlos Club

14. Igreja N. Sra. Fátima e Livraria Querigma
15. Santa Casa

16. Campo do Rui

17. Forum

18. Balão do Bonde da Vila Nery

19. Igreja Santo Antônio (Vila Prado)

20. Rodoviária

21. Kartódromo

22. Shopping Passeio São Carlos

23. Hospital-Escola

24. Universidade Federal de São Carlos

25. Carrefour (Santa Felícia)

26. Sesi

27. Parque Ecológico

28. Cemitério N. Sra. do Carmo 
ALVES, S. A Matemática do GPS. Revista do Professor de Matemática, 2005.

ATRACTOR. Construção de fio esticado: hipérbole. 2014. Disponível em: <https://youtu.be/ ETV_bWAPOqU>.

BRASIL. Ministério da Educação. Base Nacional Comum Curricular. Brasília, 2018.

FINI, M. I. C. Currículo do Estado de São Paulo: Matemática e suas tecnologias. São Paulo:SEE, 2012. Disponível em: <http://www.educacao.sp.gov.br/a2sitebox/arquivos/ documentos/783.pdf>.

LINARES, J. L. Sistema de Navegação Hiperbólico -V76- Cálculo II FZEA USP. 2016. Disponível em: <http://eaulas.usp.br/portal/video.action?idItem=7157>.

PEREIRA, M. R. d. O. O abandono de ensino de geometria: uma visão historica. Dissertação (Mestrado) - PUC-SP, 2001.

ROUSSEAU, C.; SAINT-AUBIN, Y. Matemática e atualidade. [S.1.]: Editora SBM, 2015. v. 1. SEGANTINE, P. GPS sistema de posicionamento global. [S.1.]: São Carlos EESC/USP, 2005. 


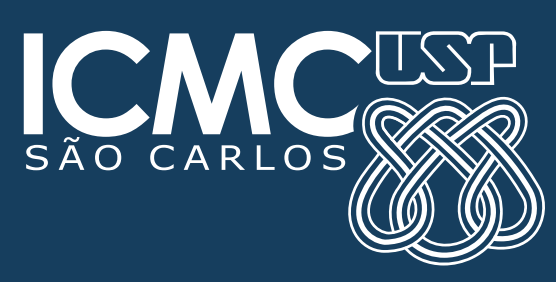

